\title{
5. Structure of the cell wall and cell contents
}

\subsection{Principal cell-wall structure - Form and stability}

The cell wall of seed plants principally consists of several layers: the middle lamella, the primary, secondary and tertiary wall, a concept presented by Evert 2006. Secondary walls consist of macro-fibrils. They are visible under the light microscope. However, the micro-fibrils are only visible in longitudinal sections of compression wood in conifers (see Chapter 10.4.1, Fig. 10.105) and under the electron microscope. In reality, there is a great chemical and morphological diversity in cell-wall structures (Evert 2006).

The middle lamella and the primary walls are optically difficult to distinguish. Primary walls are thin and consist of irregularly distributed micro-fibrils, which are embedded in a matrix of hemicellulose and pectin. Therefore they disappear in polarized light. The links between the micro-fibrils are not permanent and can be dissolved by enzymes. Therefore, cell-wall expansion is possible.
The secondary walls are normally thick and lignified. They start to form after cell expansion is completed. Characteristic at electron-microscopic scale are the helically oriented macro-fibrils consisting of cellulose and hemicellulose. They are embedded in lignin. The direction of the macro-fibrils changes within the wall but they always remain helically oriented. Due to the crystalline structure of the cellulose, secondary walls are anisotropic and are visible under polarized light. The links between the macro-fibrils are permanent; therefore the size of the cell remains stable after its formation. Secondary walls provide mechanical support against gravity and turgor pressure.

The tertiary wall is normally thin, and often covered with warts. Micro-fibril orientation is random and they are therefore not visible under polarized light. Layered cellulosic cell walls occur in all taxonomic units of vascular plants, in all habitats, from the desert to the water.

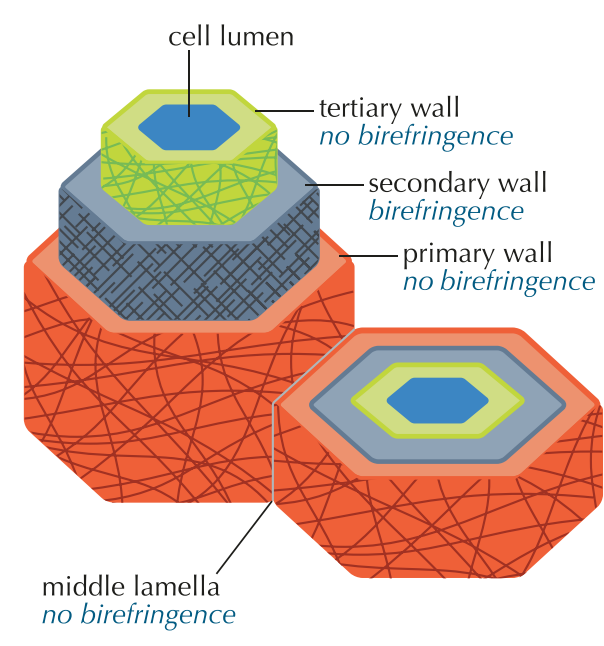

5.1 Cell walls of vascular plants consist of the middle lamella, the primary, secondary and tertiary wall.

\section{Principal structure of cell walls}

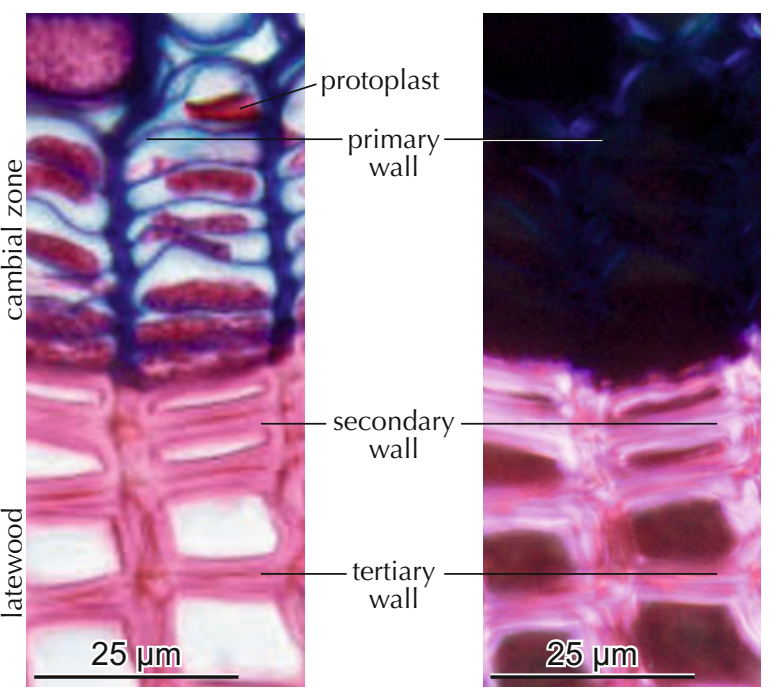

5.2 Latewood (red) and cambium (blue) of Larix decidua shown in transmitting (left) and polarized light (right). Cell walls in the cambial zone are not lignified and consist only of primary walls. They therefore disappear in polarized light.

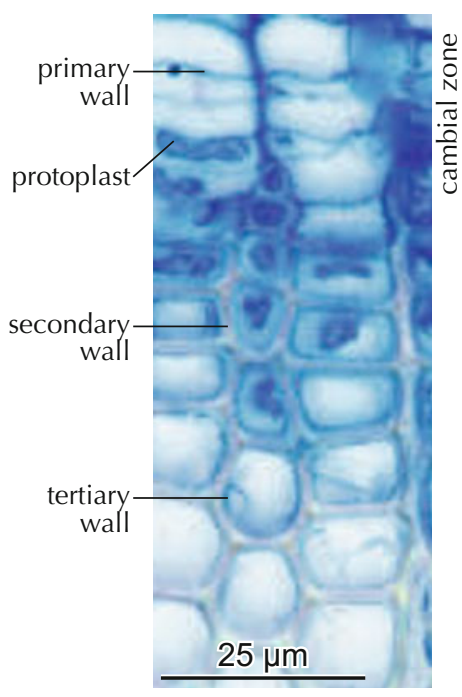

5.3 Latewood of Picea abies in formation. Thin tertiary walls (blue) appear immediately after the formation of secondary walls (light). 


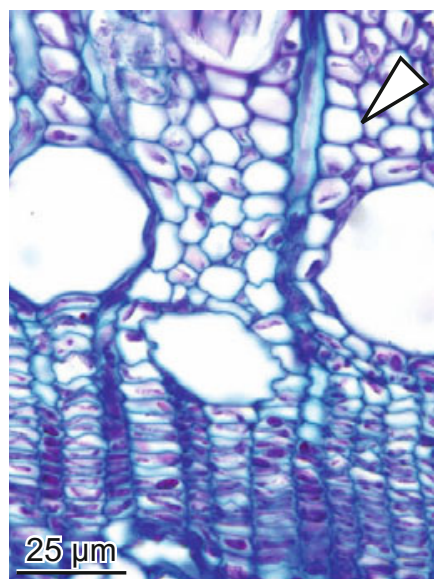

5.4 Primary walls without lignification in the cambium area of a stem of Corylus avellana. All cells, except vessels, contain protoplasts.

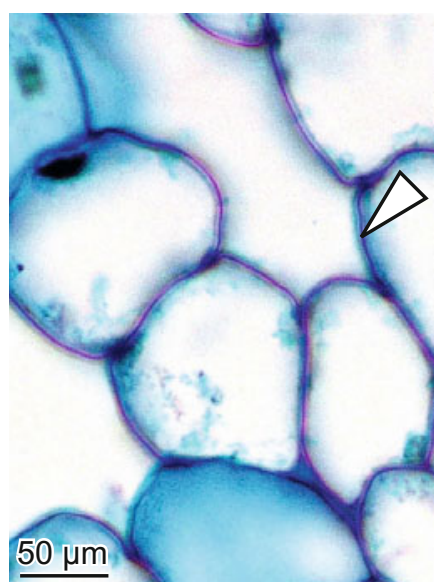

5.5 Fully developed primary walls and rudimentary walls in all cells of the water plant Ranunculus trichophyllus.

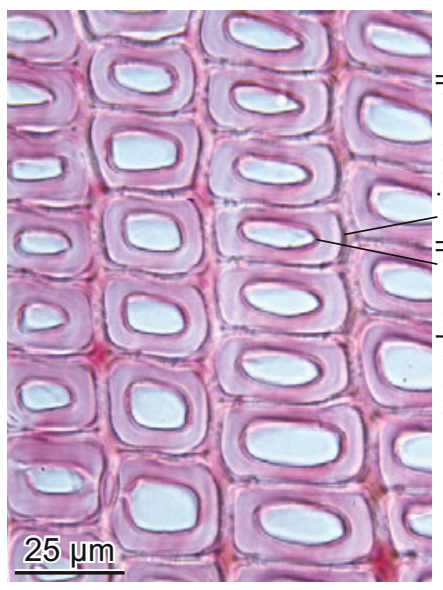

5.6 Fully developed cell walls with primary, secondary and tertiary walls of tracheids in the latewood of the conifer Pinus elliottii.

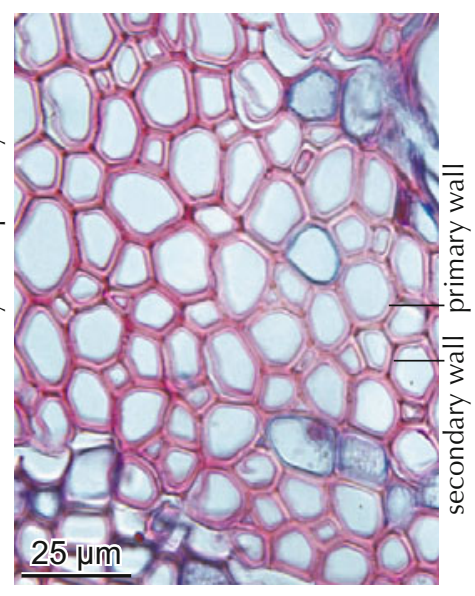

5.7 Fully developed cell walls with primary and secondary walls of fibers in the xylem of Juglans regia. Tertiary walls are only visible in the parenchyma cells.

Secondary walls
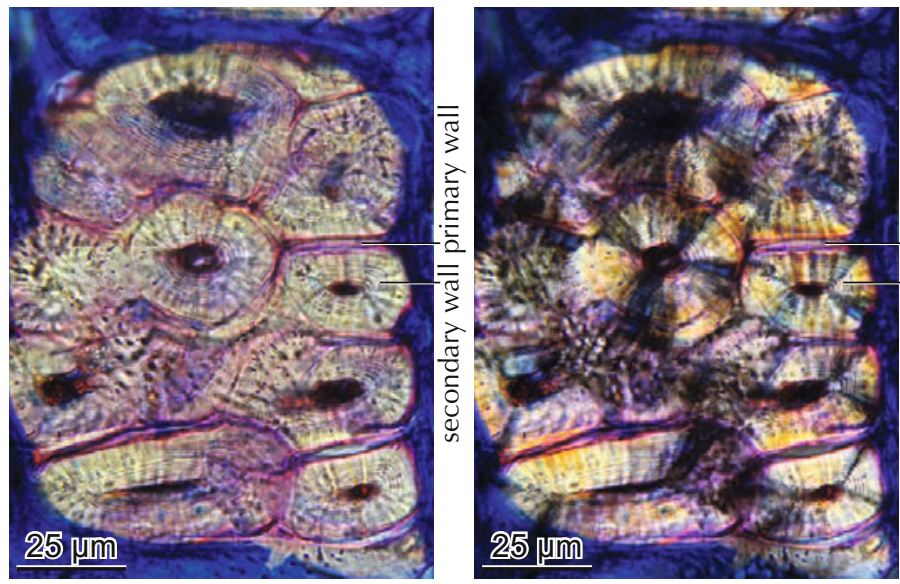

5.8 Multilayered cell walls of sclereids in the phloem of Picea abies in normal and polarized light.

primary wall

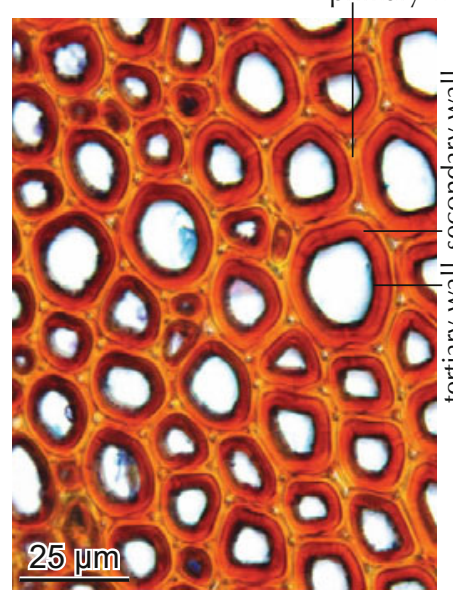

5.11 Cell walls of fern fibers (Lygodium sp.) are constructed the same as in seed plants. Visible are middle lamella, primary, secondary and tertiary walls.

Cell walls of ferns and fungi

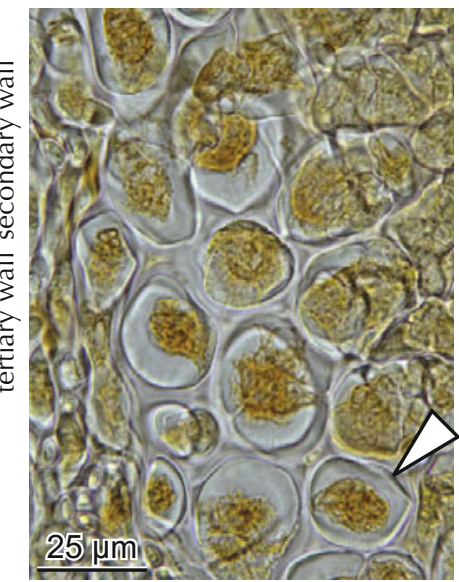

5.12 The unstructured cell walls of marine algae (Fucus serratus) consist of cellulose and glycoproteins.

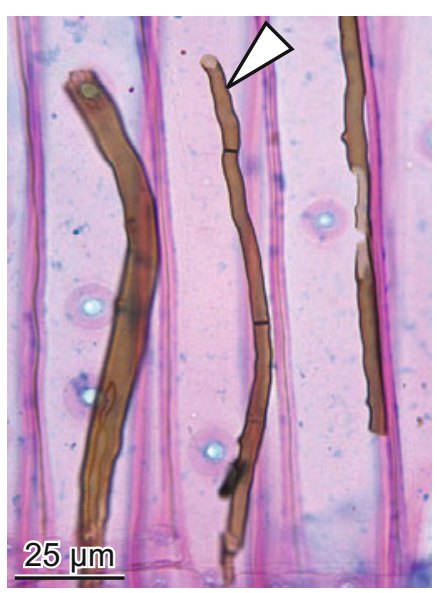

5.13 The unstructured cell walls of the blue-stain fungus Grosmannia clavigera consist of chitin.

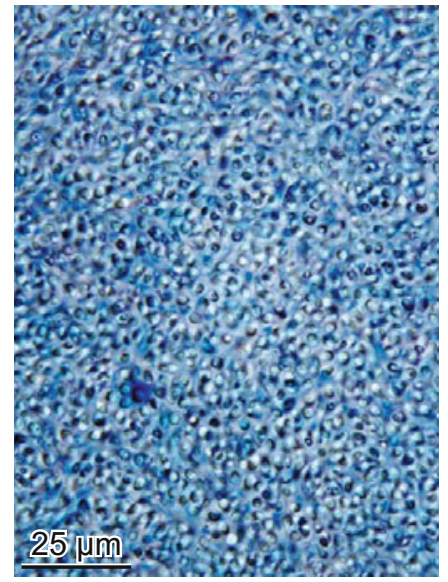

5.14 Unstructured cell walls of fungi in the lichen Usnea barbata. 


\subsection{Pits - Lateral contact between cells}

Cells communicate with each other. Two neighboring cells are anatomically connected by pits. Through their channels, cells communicate physiologically. There are two principal structures; simple pits and bordered pits. However, many transition forms exist.

\section{Simple pits}

Simple pits occur in all vascular plants. They form a channel through the secondary wall of neighboring cells. The unlignified middle lamella in the pit blocks the channel but is perforated by plasmodesmata (not visible with light microscopes), through which sugars, amino acids, hormones and nutrients can flow. Simple pits of different forms occur in axial parenchyma cells, horizontal parenchymatic ray cells, rays and fibers. If simple pits connect rays and vessels they are called vessel-ray pits.

The form and size of the opening varies. Pits in parenchyma cells are round, and those in fibers are often slit-like. They can be small $(<2 \mu \mathrm{m})$ or large $(>4 \mu \mathrm{m})$ or horizontally or axially enlarged.

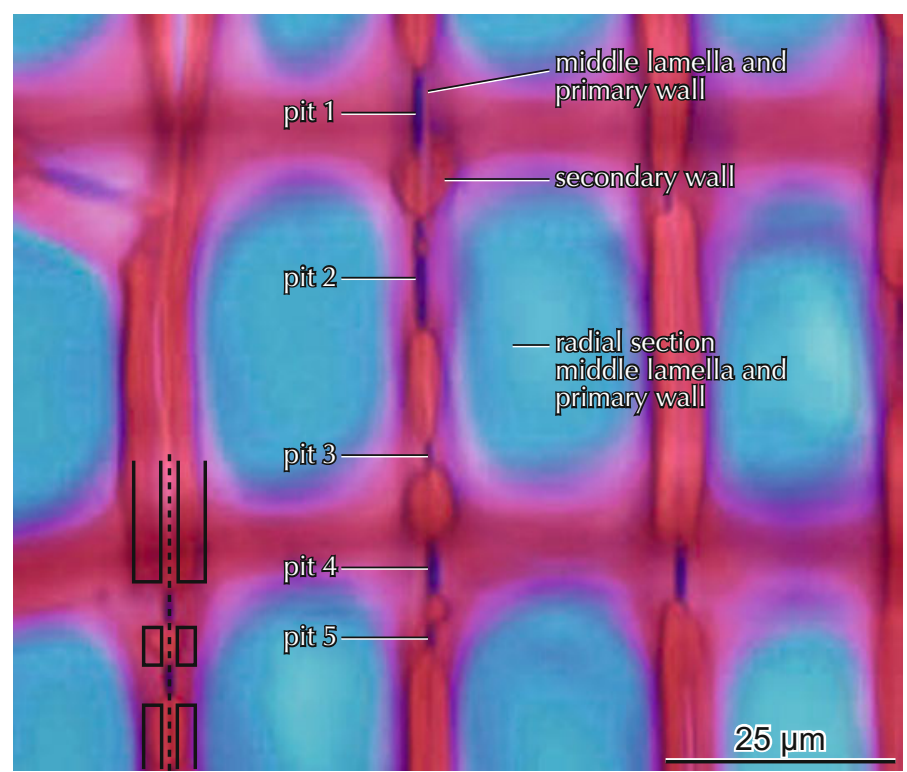

5.15 Structure of simple pits in rays of Pinus sylvestris. The middle lamellae and primary walls are not lignified (blue) in young cells.

\section{Structure of simple pits}

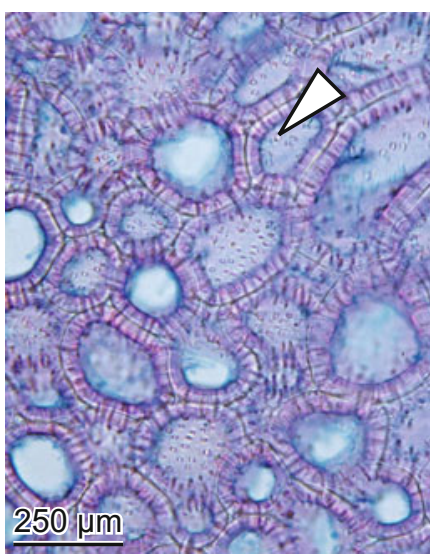

5.16 Cross section of simple pits in sclereids of hazelnut shells (Corylus avellana).

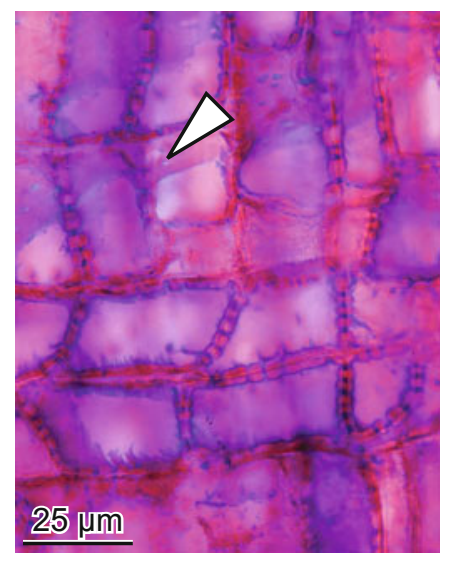

5.17 Cross section of simple pits on ray cells in Ephedra viridis.

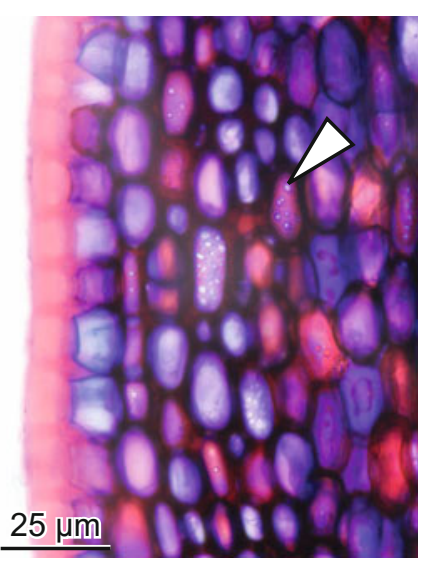

5.18 Top view of round simple pits in cortex-parenchyma cells of Rosa canina.

Size and form of simple pits

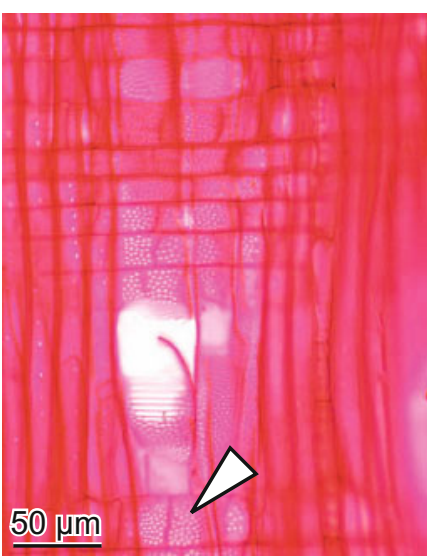

5.20 Small vessel-ray pits in the xylem of Betula aetnensis.

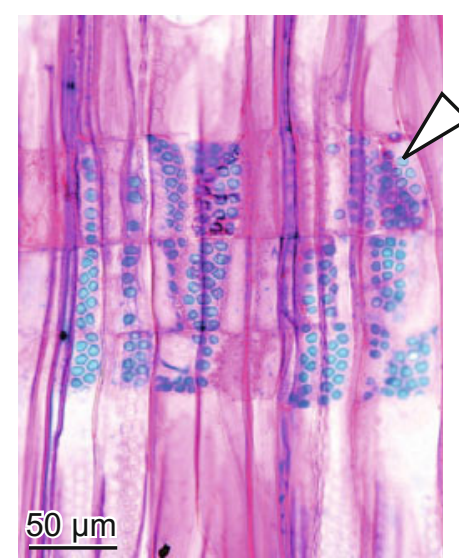

5.21 Large round vessel-ray pits in the xylem of Salix arctica.

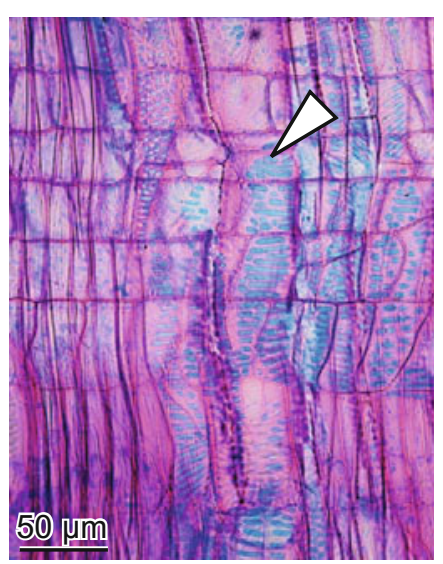

5.22 Scalariform vessel-ray pits in the xylem of Euphorbia calyptrata.

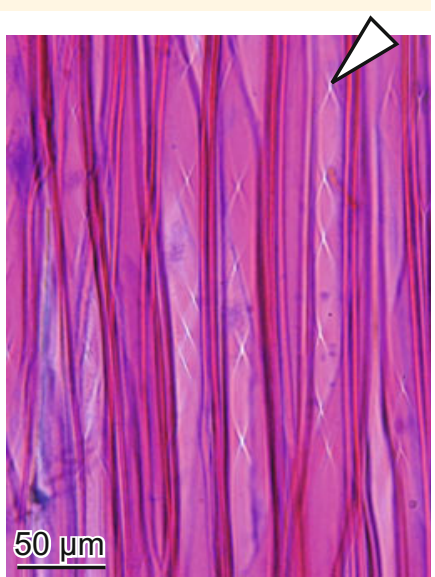

5.19 Radial view of slit-like simple pits in fibers of Magnolia acuminata.

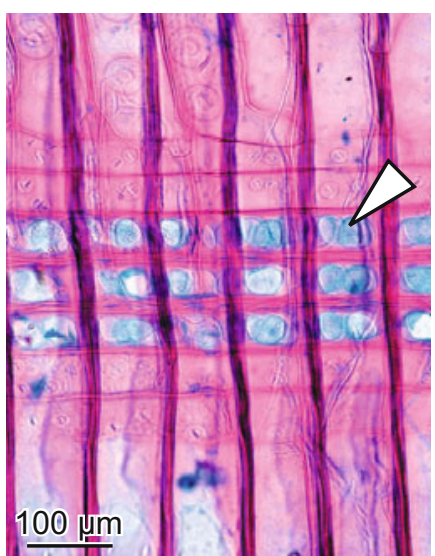

5.23 Large, fenestrate ray pits in the xylem of Pinus sibirica. 


\section{Bordered pits}

Bordered pits occur in vessels, and axial and radial tracheids. The difference to simple pits is that secondary walls arch over the pit channel and that the middle lamellae and the primary walls are thickened (torus). Tori in pits of living cells are unlignified and laterally flexible. Bordered pits with unlignified tori act as valves. If pressure in one cell decreases, e.g. by injury, the torus gets pressed to the wall with the higher pressure (healthy cell). If bordered pits connect vessels they are called intervessel pits. A special case are intervessel pits with warts on their openings, the so-called vestured pits.
The form of the outer borders, the size, and the position in a cell wall varies. They can be small $(<2 \mu \mathrm{m})$ or large $(>4 \mu \mathrm{m})$, with round or angular outlines, or horizontally enlarged (scalariform pits) or net-like (reticulate pits). Pits are mostly alternating, rarely they are arranged opposite. Bordered pits in tracheids of conifers are in one, two or multiple rows. All these characteristics are taxonomically relevant.

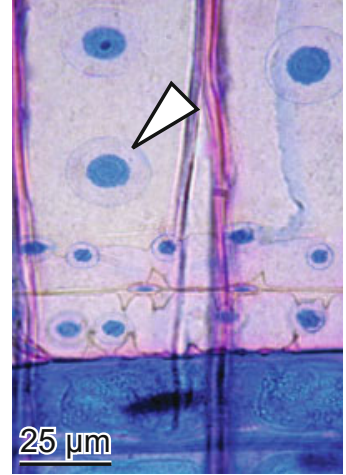

5.24 Ray tracheid in Pinus sylvestris, with unlignified tori.

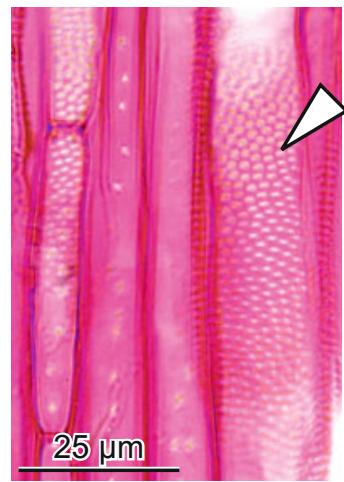

5.29 Small in Betula nana.

Structure and location of bordered pits

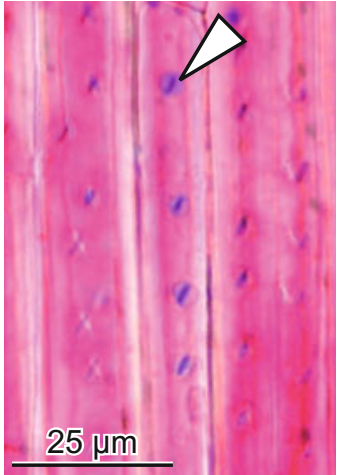

5.25 Tracheid in the dwarf shrub Sarcococca hookeriana.

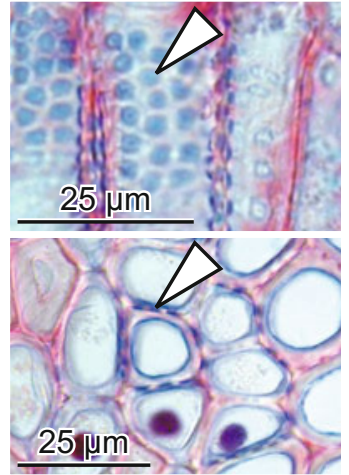

5.26 Vessels with pits in the mistletoe Viscum album, radial (top) and cross (bottom) section.

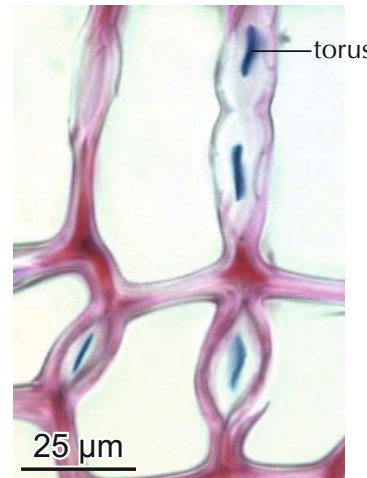

5.27 Tracheids in Picea excelsa, cross section, with unlignified tori.

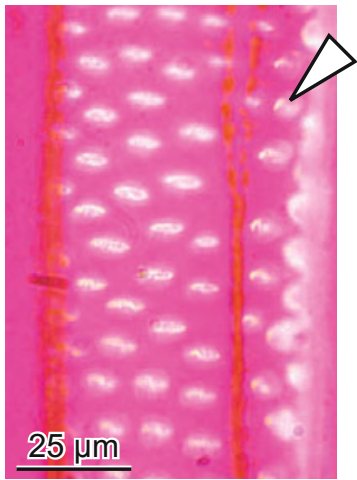

5.28 Vessel in Sinapidendron frutescens, with vestured pits.

\section{Form and arrangement of bordered pits in deciduous plants}

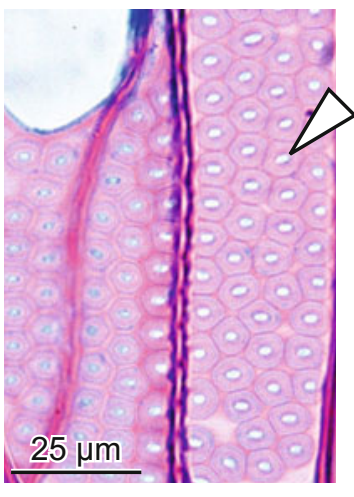

5.30 Large in Salix alba.

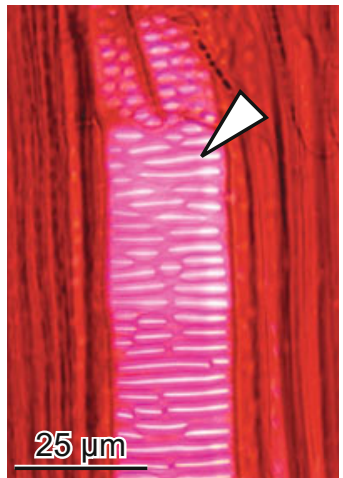

5.31 Scalariform in Ribes alpinum.

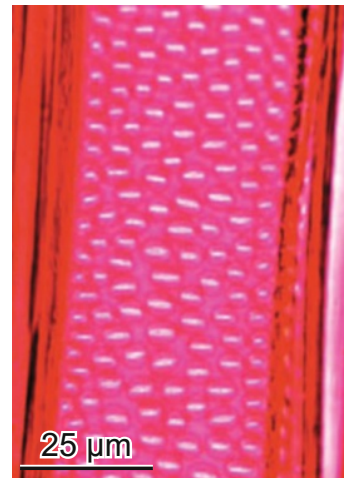

5.32 Alternate in Reseda suffruticosa.

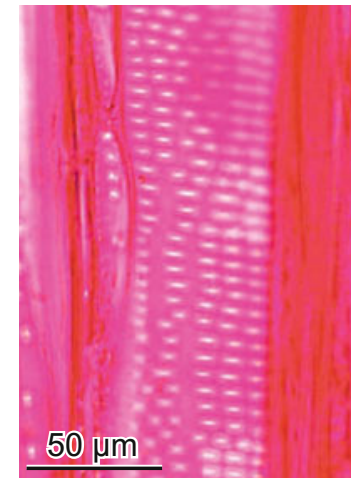

5.33 Opposite in Platanus sp.

Arrangement of bordered pits in tracheids of conifers

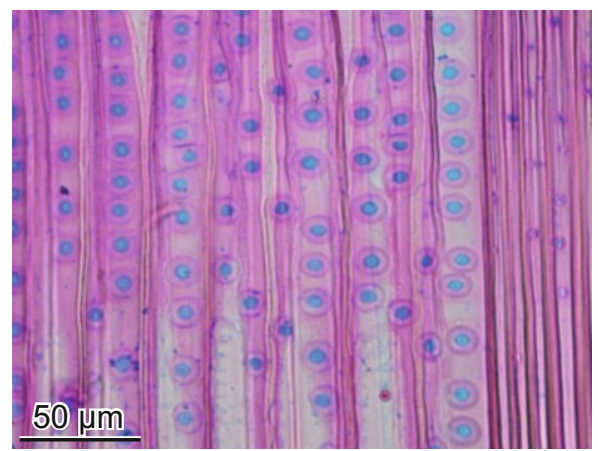

5.34 One row in Pinus banksiana.

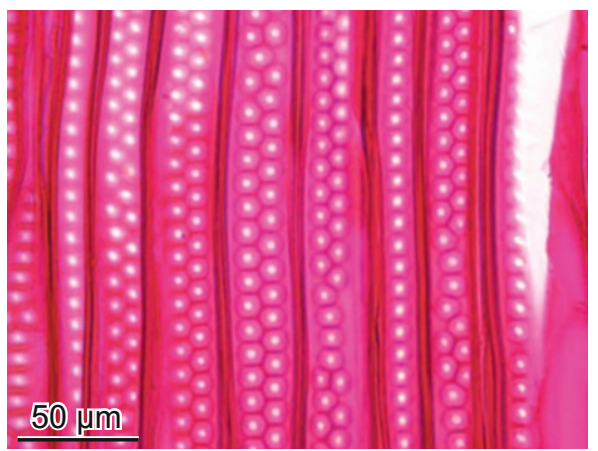

5.35 Two rows in Araucaria angustifolia.

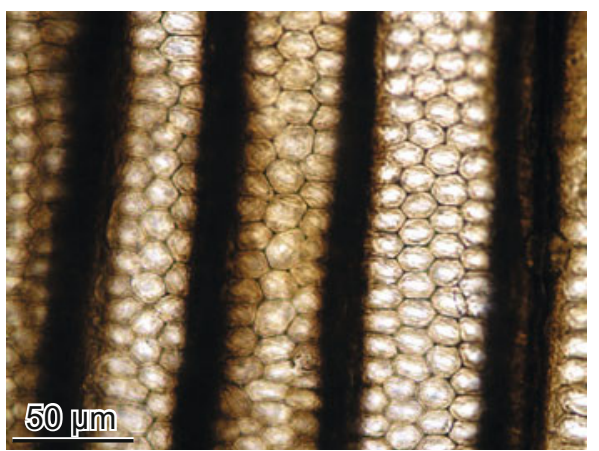

5.36 Multiple rows in the carboniferous Dadoxylon sp. 


\subsection{Perforation plates - Axial contact between vessels}

Vessels are perforated at their axial ends. The perforation plates are normally oblique positioned at their radial walls. Therefore they can be observed on radial sections.

Three perforation-plate types exist principally:

Simple perforation plates are characterized by their large, round to oval opening. The vast majority of species have simple perforations.

Foraminate perforation plates with several round openings occur only in the family of Ephedraceae, which stands taxonomically between conifers and dicotyledonous plants.

Scalariform perforation plates are characterized by their oblique position and horizontal bars. The number of bars varies from one to more than 30. The thickness of the bars and the size of the plates are also variable. The occurrence of scalariform perforation plates is species-specific. They mainly occur in larger plants from shrubs to trees. They are rare in tropical environments and in small plants. Hardly any herb has scalariform perforation plates.

Aberrant scalariform perforation plates have been observed in a few species of small plants. They occur mainly in the family of Asteraceae.

It has been suggested that foraminate perforation plates stand at the beginning of an evolutionary process of trees, which ends with simple perforation plates (Bailey 1944).

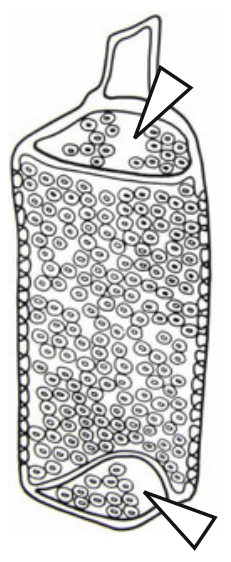

5.37 Fraxinus excelsior. Reprinted from Greguss 1945.

\section{Simple}

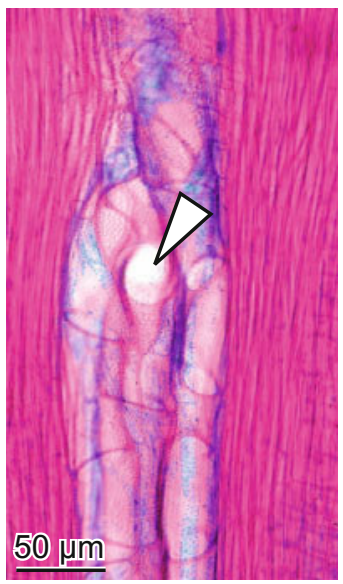

5.38 Carduus macrocephalus

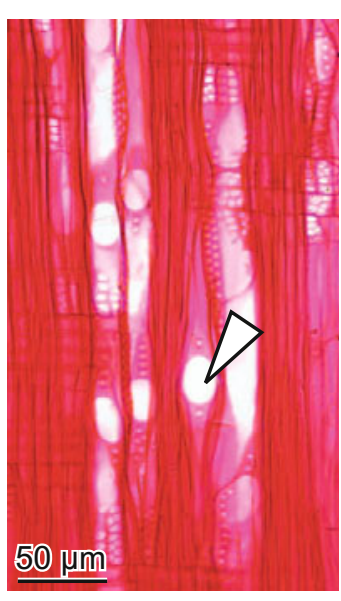

5.39 Salix helvetica
Foraminate

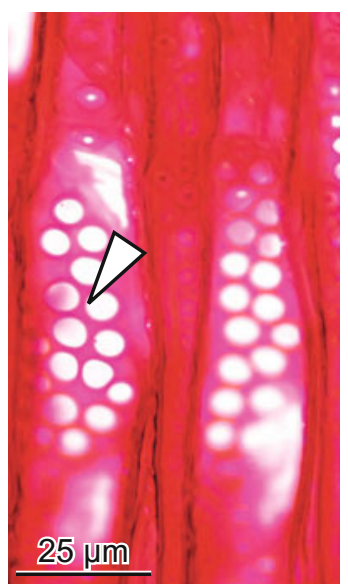

5.40 Ephedra distachya ssp. helvetica
Scalariform

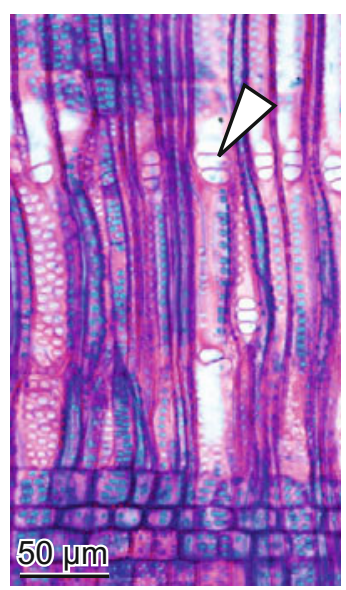

$\mathbf{5 . 4 1}<10$ bars, Paeonia fruticans.

\section{Scalariform}

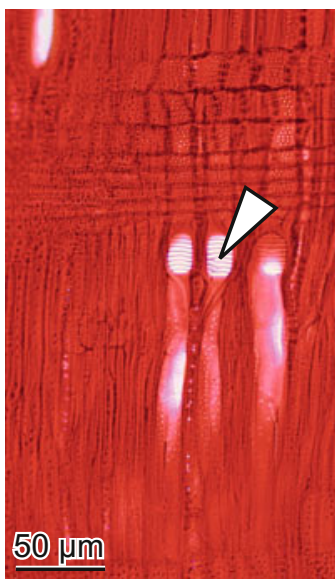

$\mathbf{5 . 4 2}<10$ bars, Buxus sempervirens.

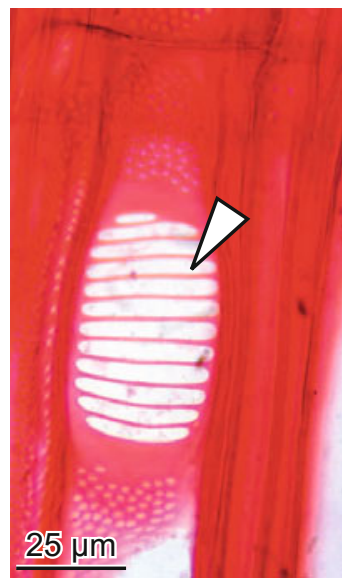

5.43 10-20 bars, Betula humilis.

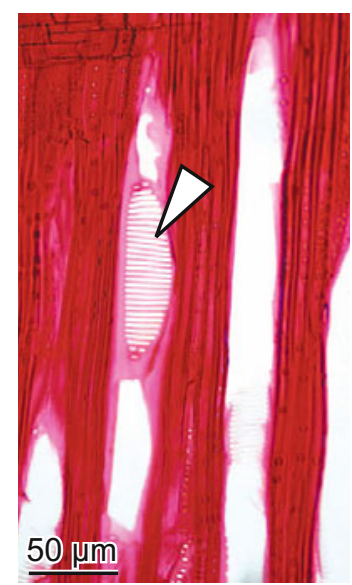

$5.44>20$ bars, Viburnum opulus.

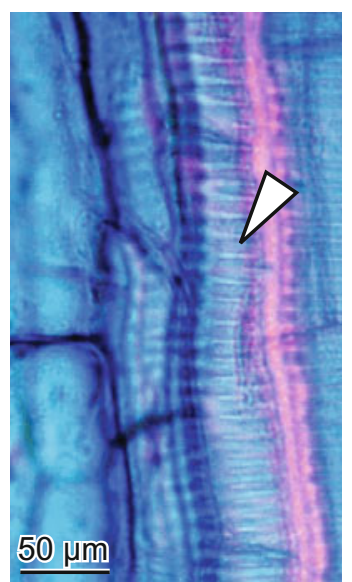

$5.45>20$ bars, Menyanthes trifoliata.

\section{Aberrant scalariform}

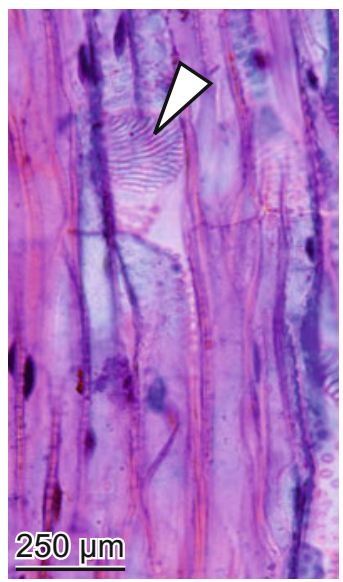

5.46 Bidens tripartita 


\subsection{Helical thickenings - Special wall thickenings}

The secondary wall in fibers, tracheids and vessels of many species occurs as annular rings, spirals or nets. Those structures are absent in parenchyma cells of the xylem. The principal function of spiral thickenings might be stabilization but their occurrence in the plant body indicates also an ontogenetic and phylogenetic component. Helical thickenings have occurred in the xylem of all taxonomic units of vascular plants since their move to the land 350 million years ago.

Annular thickenings occur exclusively in the protoxylem and metaxylem of vascular bundles. The rings represent an early ontogenetic form of secondary walls.
Helical thickenings of various thickness occur in the mature xylem. Helical thickenings are of great taxonomic value because they appear only in specific taxa:

- In the tracheids of some genera of conifers, e.g. Taxus and Pseudotsuga.

- In the tracheids and vessels of dicotyledonous plants. In some species they are thick-walled and easily visible, in others thin-walled and difficult to recognize. Variations occur also in the angle of the spiral and the density within a vessel.

Helical thickenings are not to be confused with helical cavities in the secondary walls of compression wood in conifers, or with reticulate pits in some dicotyledonous plants.
Helical thickenings in the proto- and metaxylem

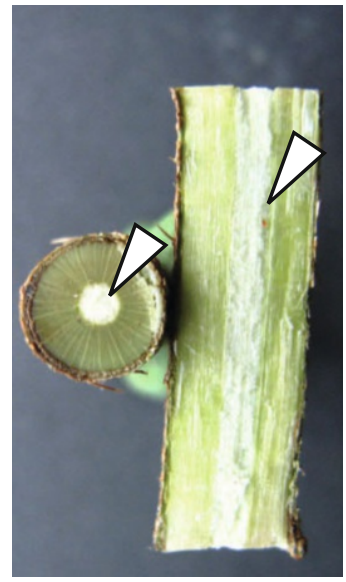

5.47 Cross and radial section of a species of Rosa. Helical thickenings occur immediately around the pith.

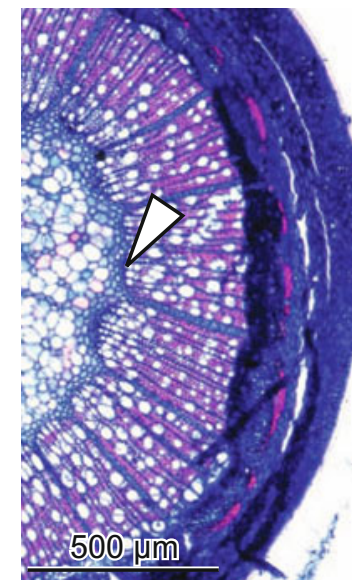

5.48 Cross section of a species of Rosa. Helical thickenings occur in vessels at the initial point of vascular bundles.

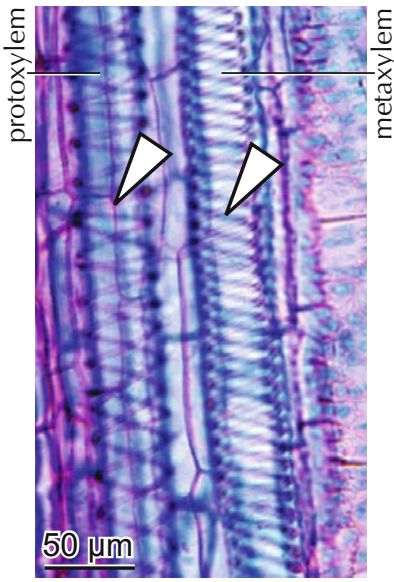

5.49 Helical thickenings in vessels of Colocynthis vulgaris. The gap between the spiral bands in the first vessel (protoxylem?) is wider than that in the second vessel (metaxylem).

\section{Helical thickenings in tracheids and vessels}

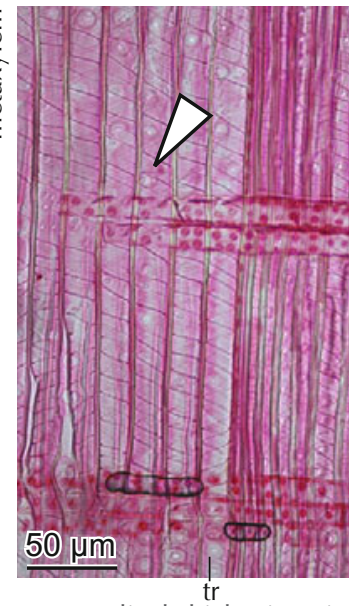

5.50 Helical thickenings in tracheids in the xylem of the conifer Taxus baccata.

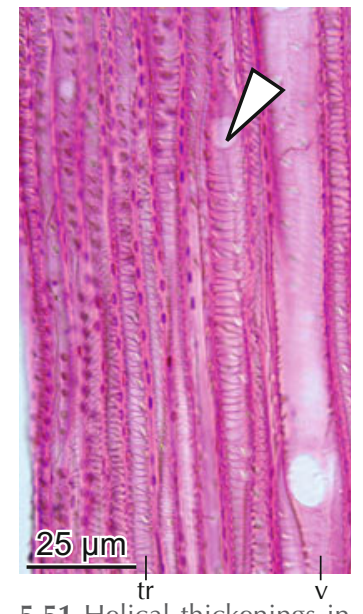

5.51 Helical thickenings in tracheids and vessels of the dicotyledonous dwarf shrub Digitalis obscura.

\section{Do not confuse}

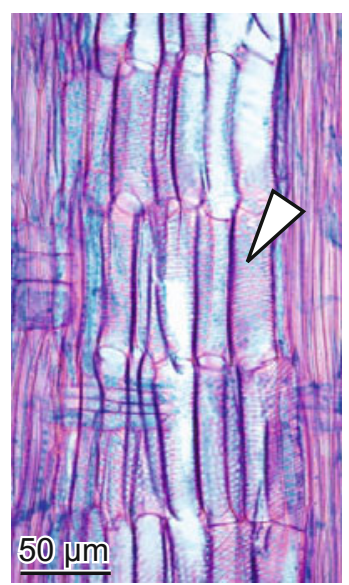

5.52 Densely positioned helical thickenings with a flat angle in Adenocarpus viscosus.

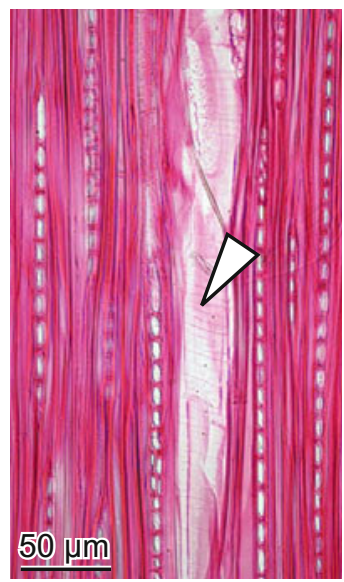

5.53 Thin helical thickenings in vessels in Tilia platy phyllos.

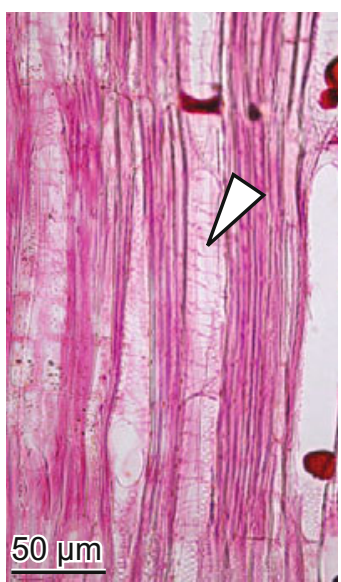

5.54 Thin helical thickenings in vessels in Lonicera xylosteum.

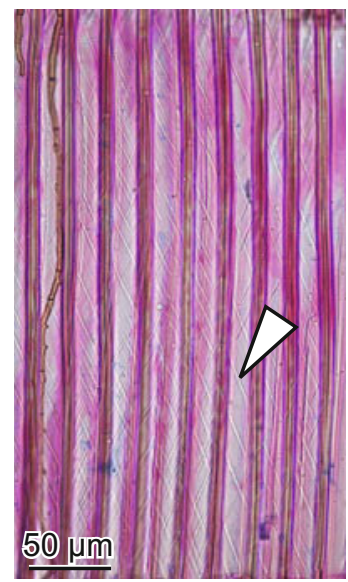

5.55 Helical cavities in compression-wood tracheids of the conifer Pinus sylvestris.

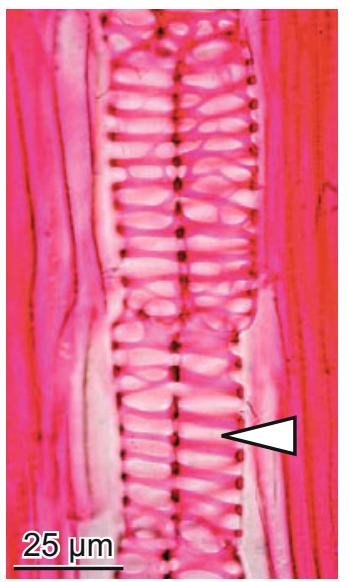

5.56 Reticulate pits with very wide openings in $\mathrm{AeO}$ nium urbicum. 


\subsection{Tyloses - Permanent interruption of water flow}

Tyloses occur in vessels. They represent an essential feature in compartmentalized parts of stems at the boundary between heartwood and sapwood, living and dead parts of branches, or in injured parts of the xylem. Tyloses block the axial water transport and defend living tissues against pathogens.

Tyloses are irregularly formed cell walls with various wall thicknesses inside vessels. Their origins are specially formed cell wall layers inside secondary walls in neighboring parenchyma cells which expand balloon-like through pit openings into the vessels. Such cells are called contact cells. Tyloses are generally unstructured and unlignified. However, tyloses with simple pits also exist. Tyloses in older tissues are often lignified and impregnated with phenols. Nuclei often migrate into the tyloses. Tyloses occur in vessels of the primary and secondary xylem of trees and herbs.

\section{Tyloses in a defense zone}

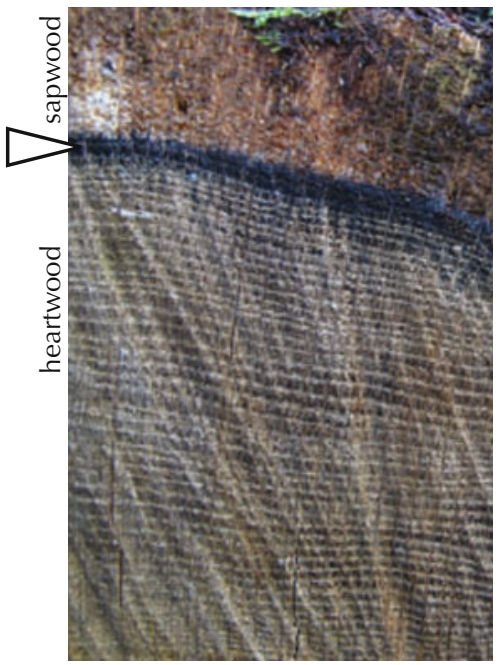

5.57 Tyloses occur at the heartwood-sapwood boundary of oaks (Quercus sp.).

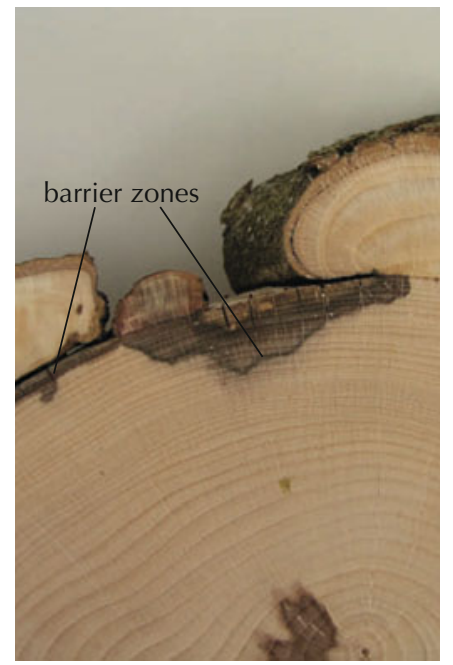

5.58 Tyloses inside an injured part of a stem of Acer pseudoplatanus.

Anatomy of tyloses

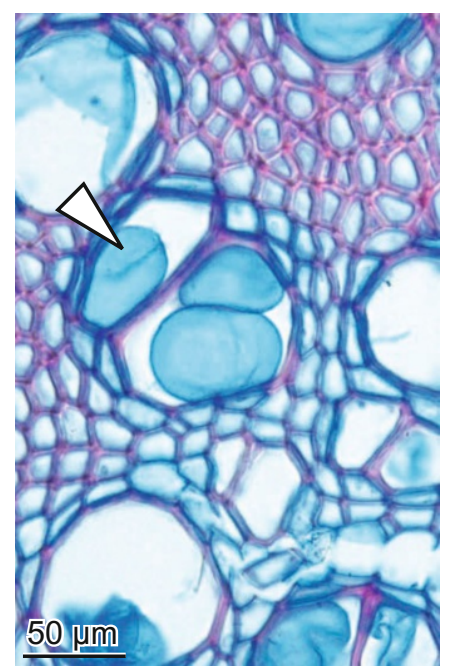

5.62 Tyloses in vessels of the nettle Urtica dioica.

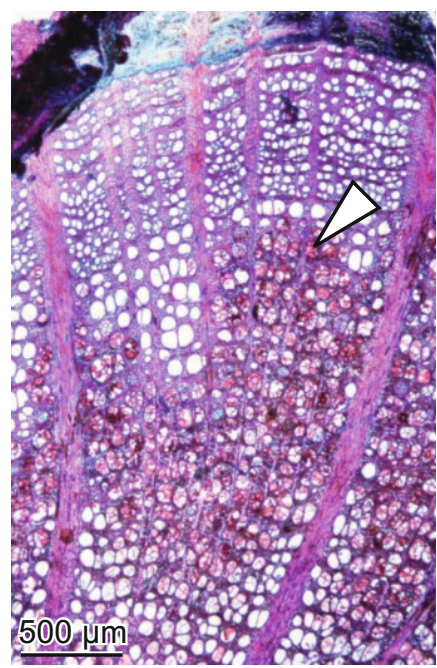

5.59 Tyloses in a defense zone (barrier zone) in a root of Fagus sylvatica.

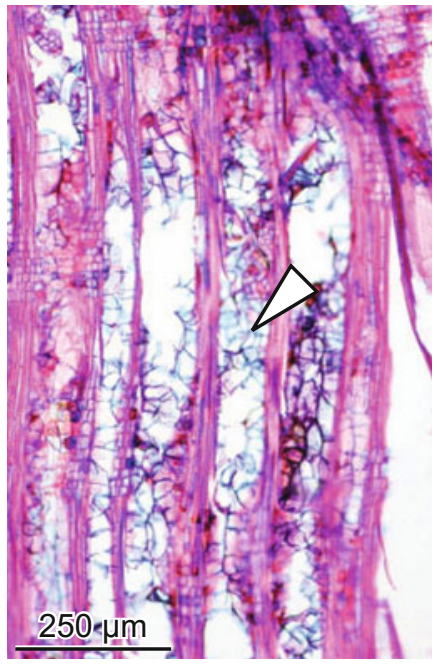

5.60 Tyloses in vessels of a defense zone block the water conductance in Fagus sylvatica.

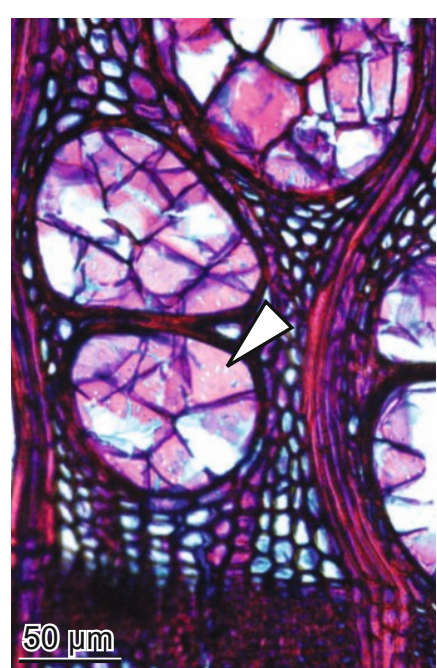

5.63 Tyloses with simple pits in Maclura pomifera.
Nuclei in tyloses

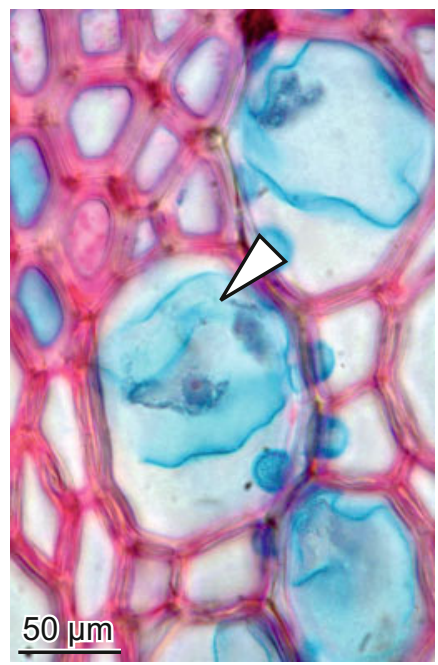

5.64 Tyloses in an earlywood vessel with nuclei in the climber Hedera helix. 


\subsection{Cell contents - Everything inside the cell wall}

Living adult cells of vascular plants principally contain a protoplast and vacuoles. The protoplast is the living unit of a cell. It is separated by the tonoplast (semipermeable thin biomembrane) from the vacuole. The protoplast contains a liquid (cytoplasm) in which various organelles such as the nucleus with nucleolus, plastids (starch grains, chloroplasts, chromoplasts, leucoplasts), mitochondria, the endoplasmatic reticulum, Golgi vesicles and ribosomes occur. The vacuole contains ergastic substances such as crystals, oil bodies and various types of phenols. Most organelles contain genetic information.

5.65 Schematic representation of an adult cell. Visible by light microscopy are nuclei, starch grains, chloroplasts, chromoplasts, crystals, oil bodies and phenols.

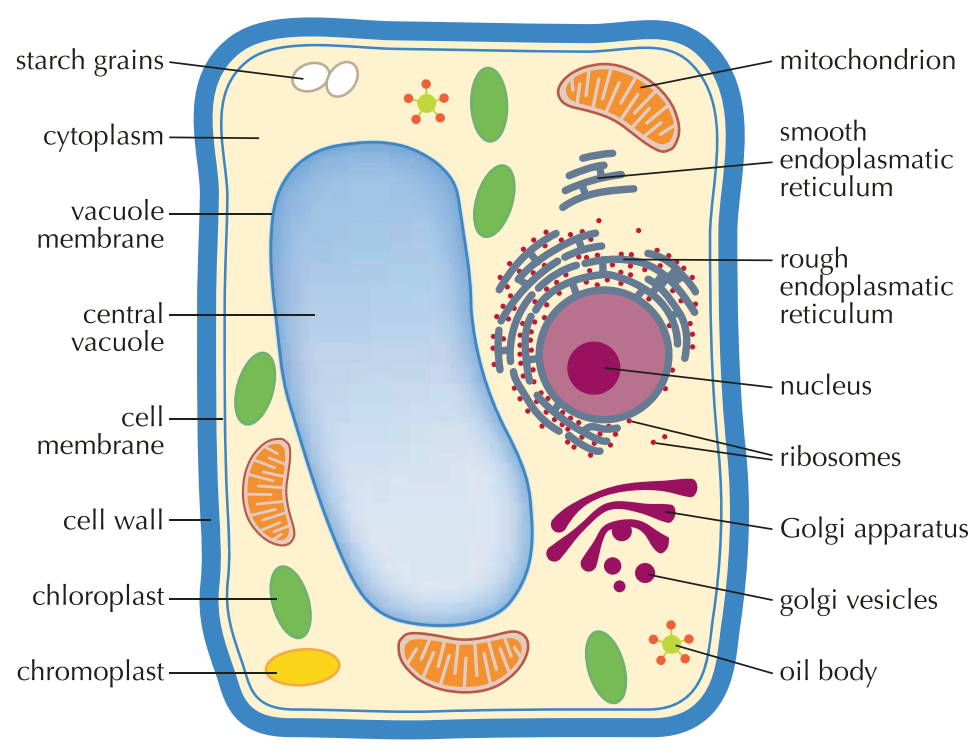

5.6.1 Nuclei in protoplasts - Metabolic centers of the plant cells

The cell nuclei are the basic structural and functional unit of organisms. They occur in all cell types and all organs of plants, however, their life span greatly varies.

5.66 Nuclei in a secondary cambium and rays of the dwarf shrub Viscum album, radial section.

Nuclei in parenchyma cells

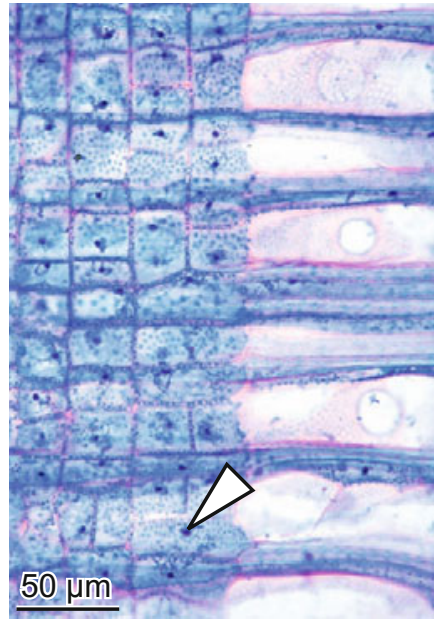

5.67 Small, round, 80-year-old nuclei in ray cells of the arctic dwarf shrub Rhododendron lapponicum.

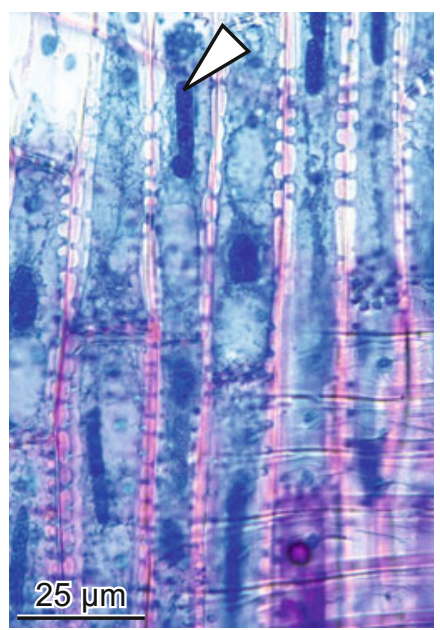

5.68 Radially elongated nuclei in young ray cells of the conifer Abies alba.

\section{Nuclei in meristems}

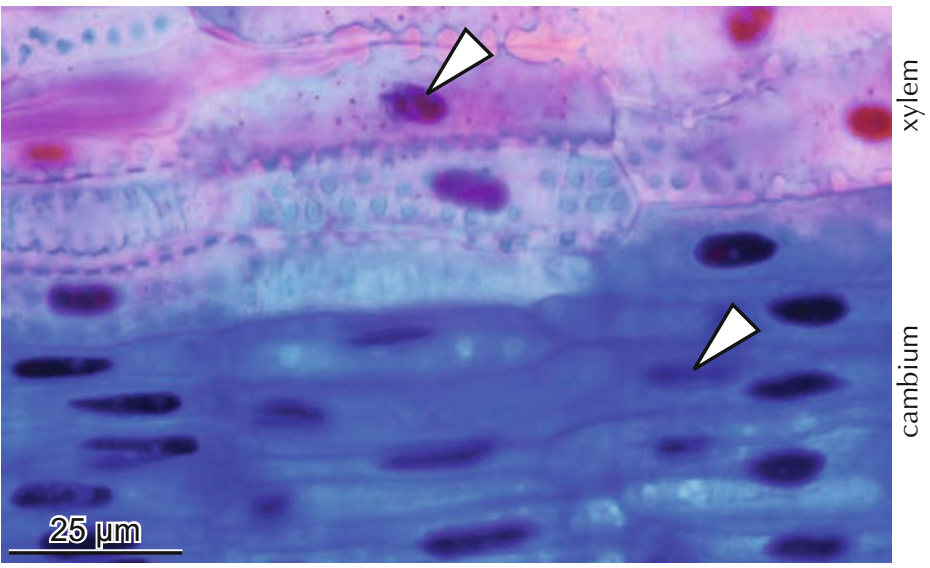

Nuclei in tracheids and fibers

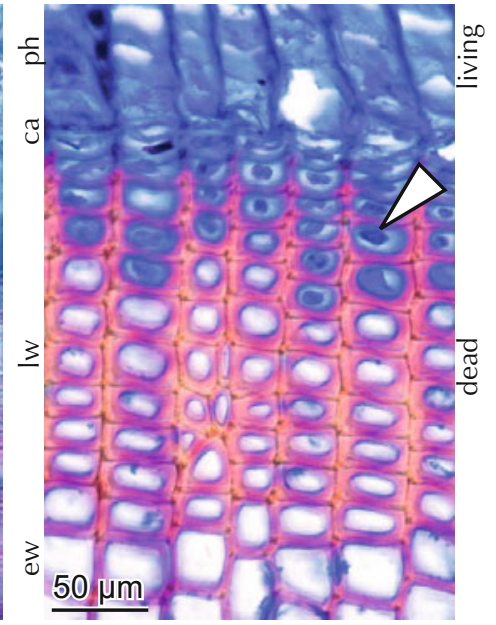

5.69 Protoplast and nuclei in latewood tracheids of the conifer Pinus sylvestris, cross section. Only the most recently formed tracheids are living, they contain protoplasts.

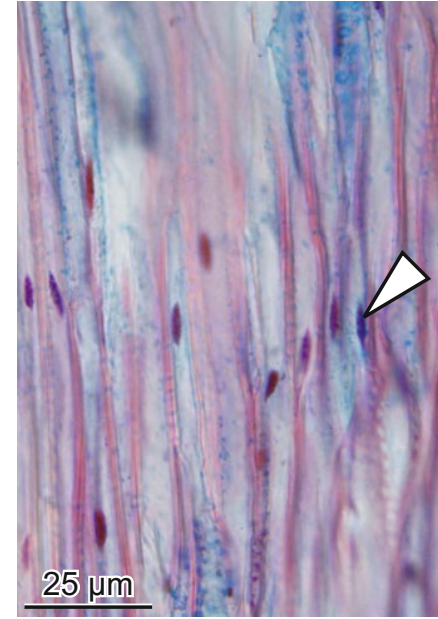

5.70 Nuclei with pointed axial ends in fibers of the herb Anthemis palestina in the desert, radial section. 


\subsubsection{Plastids - Green, yellow and white bodies}

All living cells contain plastids. Chloroplasts are green-pigmented plastids. They contain the green photosynthetically active chlorophyll and the yellow carotenoids. Chromoplasts are yellow-pigmented plastids and contain carotenoid pigments. Leucoplasts are non-pigmented plastids.

Chloroplasts occur in all green parts of plants. They represent a substantial part in leaves (10-200 chloroplasts per cell) but also occur in parenchymatic parts of stems and fruits. Disk-like bodies, the thylacoids, are only visible in electron-microscopic magnifications.
Chromoplasts occur mainly in yellow- and orange-pigmented parts of plants such as in flowers, fruits and roots. Chromoplasts are also a product of aging chloroplasts in leaves.

Leucoplasts do not contain pigments. Some types can develop into chloroplasts or chromoplasts under the influence of light.

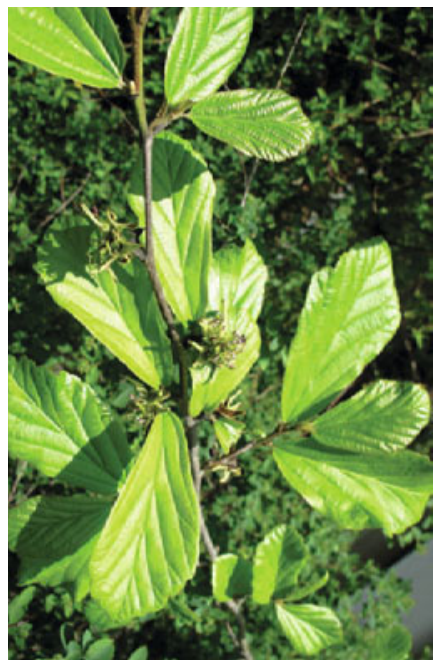

5.71 Green leaves contain chloroplasts. Hamamelis virginiana.

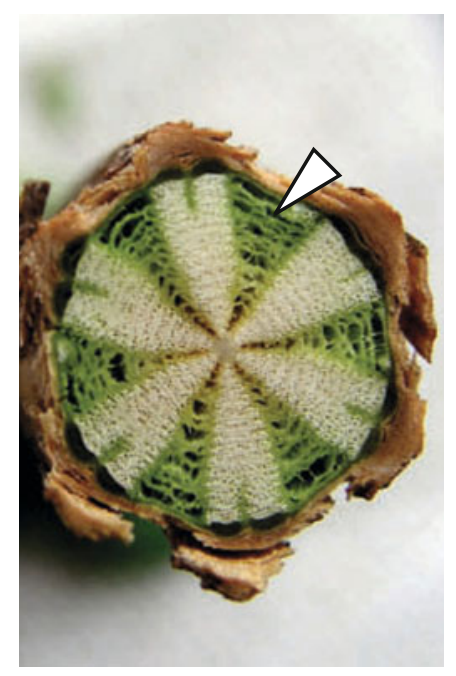

5.72 Green parts of stems contain chloroplasts. Clematis alpina.

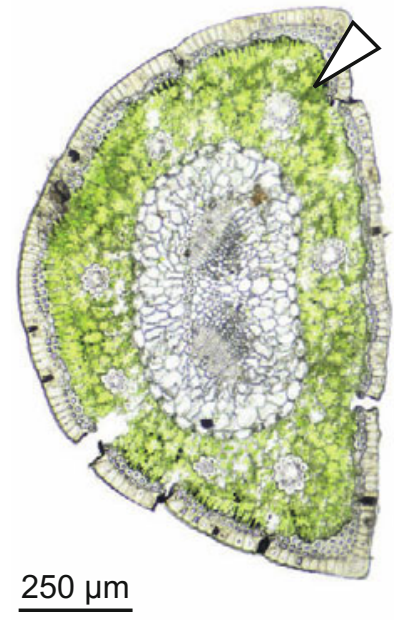

5.73 Chloroplasts in the needle of Pinus nigra.

\section{Chromoplasts make the world colorful}

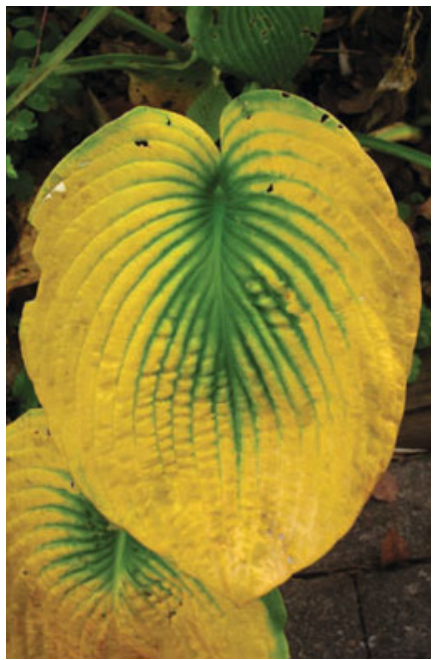

5.75 Aging leaves of Hosta sp. lose their chlorophyll, and yellow carotenoids now characterize the aspect.

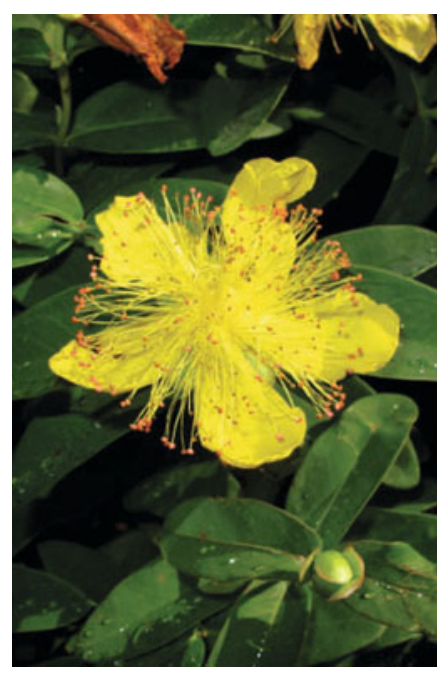

5.76 Yellow flowers of Hypericum sp. contain chromoplasts.

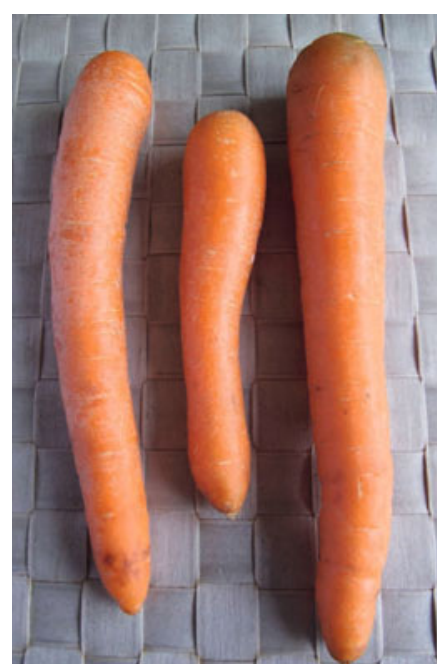

5.77 Orange carrots (Daucus carota) contain chromoplasts.

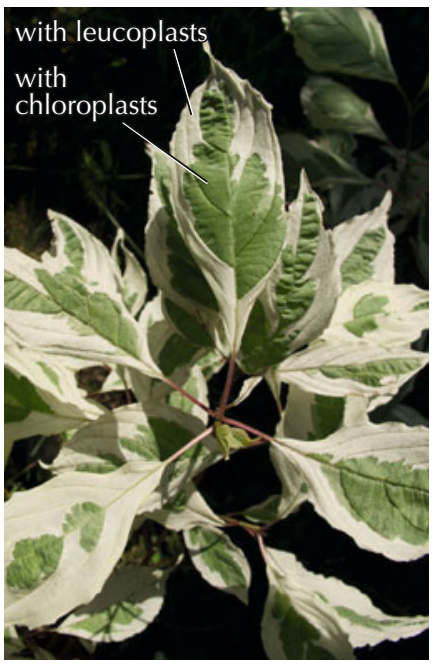

5.74 Chloroplasts and leucoplasts in a variegated leaf of Cornus sericea.

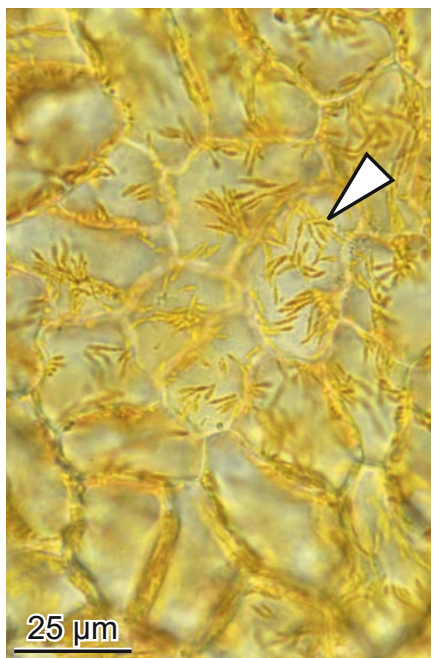

5.78 Chromoplasts in the petal of Lonicera tatarica. 


\subsubsection{Starch grains - Stored energy}

Starch is a carbohydrate and plays a fundamental role for life on earth. Without starch from potatoes, manihot or cereals such as wheat, corn, rice and many others, human existence is unimaginable. Starch stores the energy of polysaccharides in a non-osmotic efficient way in parenchyma cells in all parts of all vascular plants. When sugars are re-synthesized to starch, the grains are called amyloplasts.

Starch as the base for (human) life

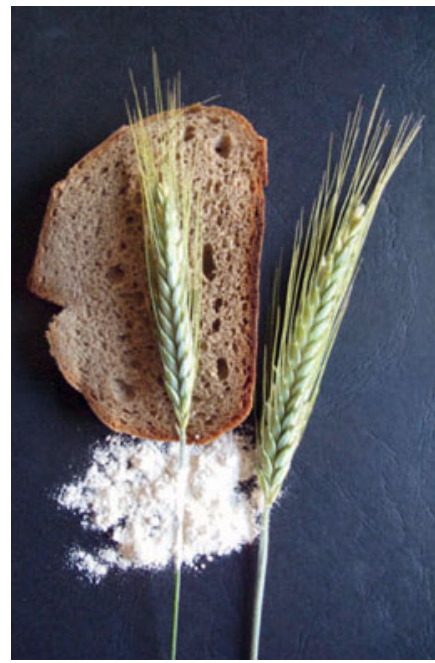

5.79 Flour from cereals.

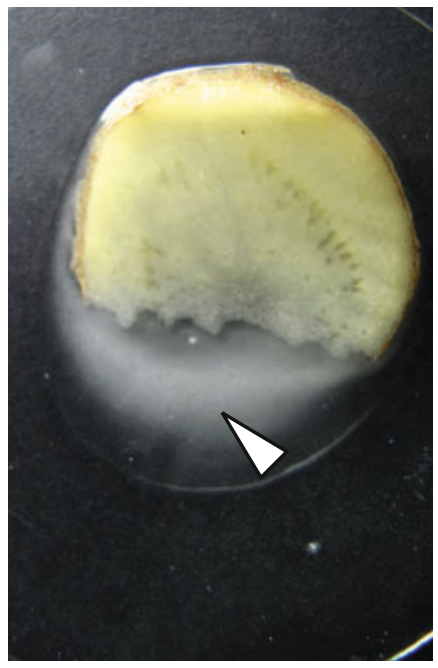

5.80 Section of a potato (Solanum tuberosum) with starch flowing out.
Starch grains are easy to recognize under the microscope in polarized light by the characteristic "Maltese cross", or by staining with potassium iodide. Form and size of the grains vary. In most cases they are more or less globular with a central point (hilum). Layers are the result of alternating deposits of different polysaccharides.

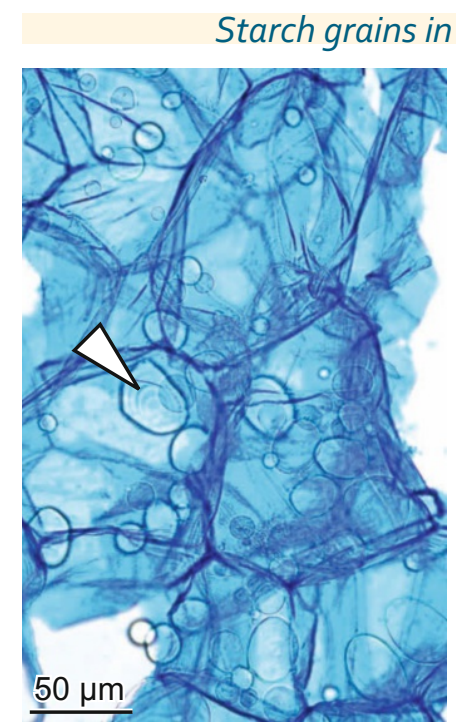

5.81 Large starch grains in Solanum tuberosum.
Starch grains in shoots

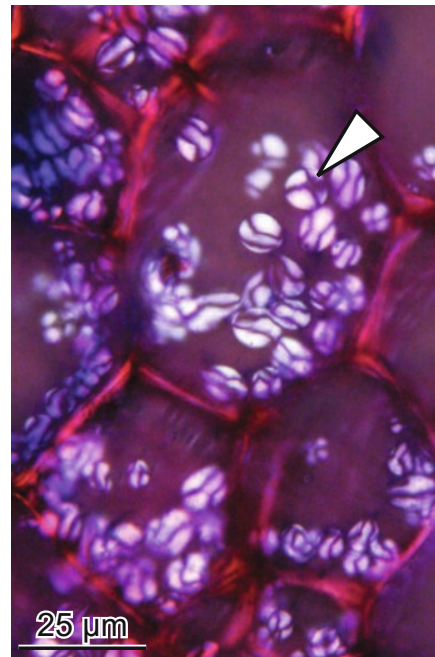

5.83 Starch in the pith of a rhizome of the herb Tellima grandiflora, polarized light.

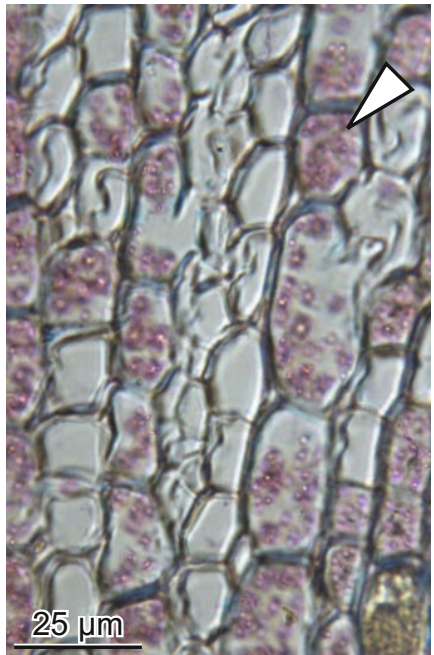

5.84 Small starch grains in rays and axial parenchyma cells in the xylem of a twig of Fraxinus excelsior, cross section.

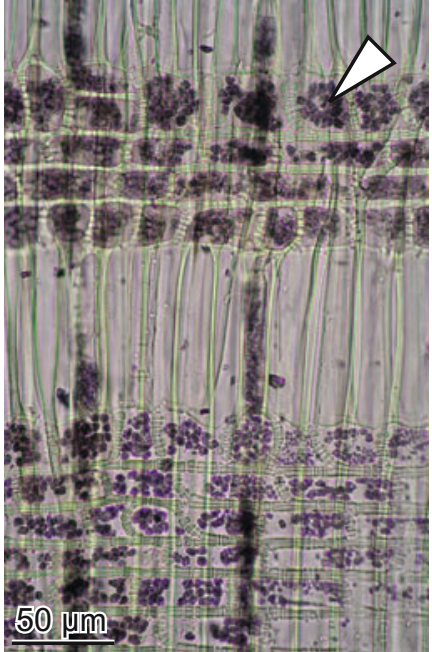

5.85 Starch stained with potassium iodide in ray cells of the wood of Abies alba, radial section.

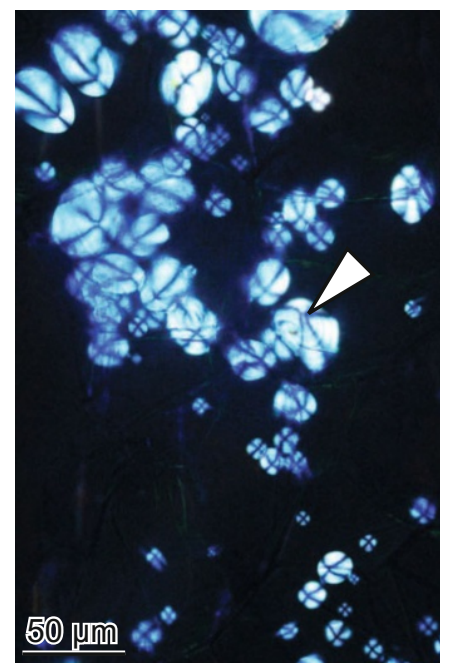

5.82 Starch in Solanum tuberosum with the characteristic "Maltese crosses" seen in polarized light.

Starch grains in fruits

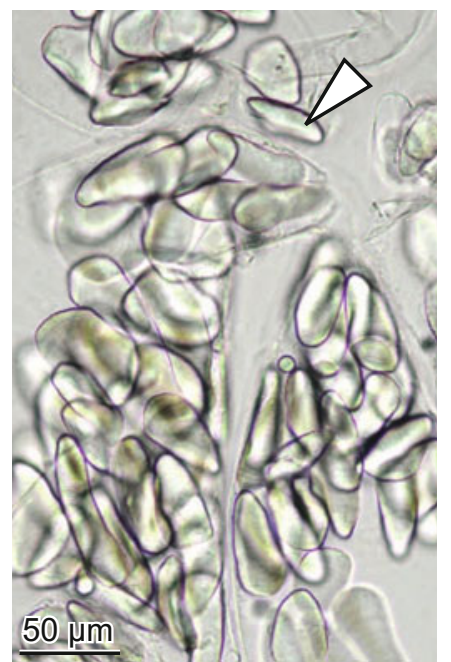

5.86 Starch in the soft fruit of a banana (Musa $\times$ paradisiaca). 


\subsubsection{Crystals in vacuoles - Regulators and metabolic waste}

Crystals are excreted from protoplasts and deposited in vacuoles. Most crystals in cells are calcium oxalates. They have two major functions. Calcium is an essentially required element for plant growth, therefore calcium oxalate crystals often occur in meristematic tissues where calcium ions regulate the transport of organic molecules. Calcium oxalate is an end product of metabolic processes (metabolic waste), therefore calcium oxalates are often deposited in vacuoles of adult cells in all

\section{Crystals in meristematic tissues}

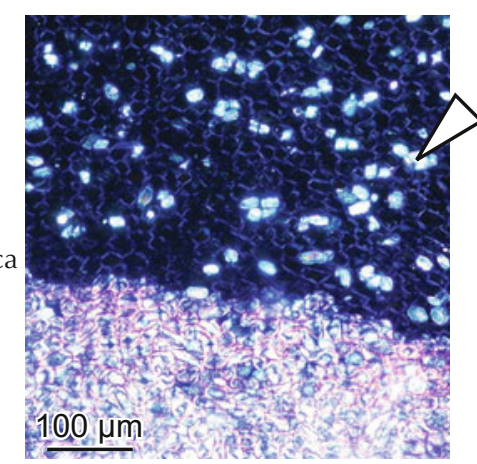

5.87 Crystals in the meristematic tissue of a bud of Acer pseudoplatanus, polarized light.
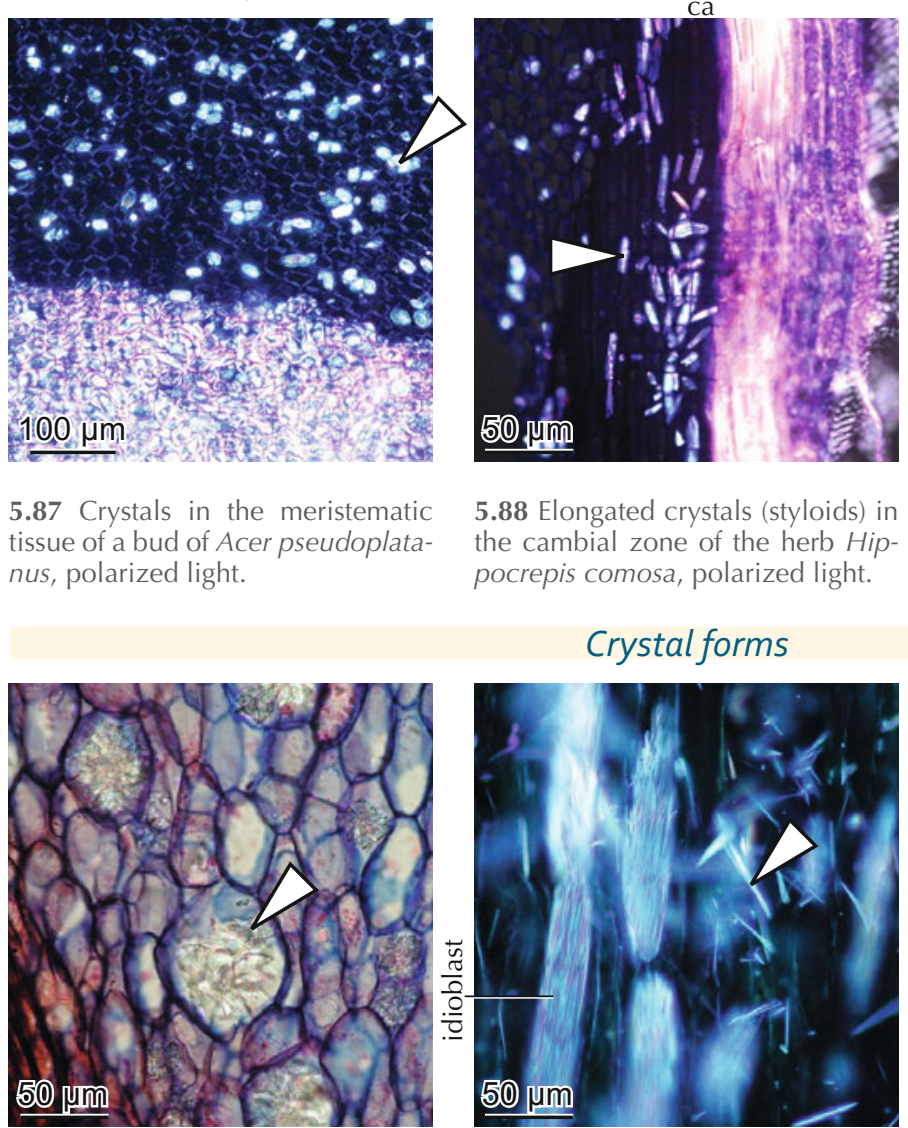

5.91 Crystal druses in expanded cells of the cortex of the alpine herb Astrantia major, polarized light.

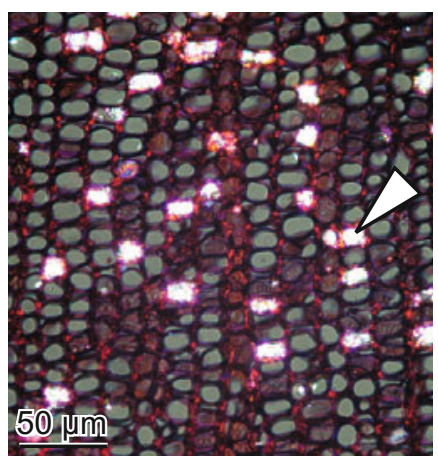

5.95 Irregularly dispersed crystal druses in the phloem of the shrub Buxus sempervirens, polarized light.

parts of plants, where they remain until cell death. Some plants form special cells, so-called crystal idioblasts, where crystals are deposited.

Calcium oxalate crystallizes in the form of prismatic crystals of various shapes: as druses, raphides and irregular small grains. The distribution and shape of calcium oxalates in tissues is a valuable taxonomic feature.

\section{Crystal forms}

5.88 Elongated crystals (styloids) in the cambial zone of the herb Hippocrepis comosa, polarized light.

\section{Crystal forms}

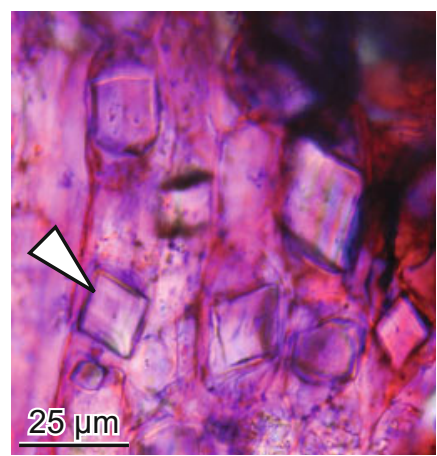

5.89 Prismatic crystals in a xylem ray of Fagus sylvatica, polarized light.

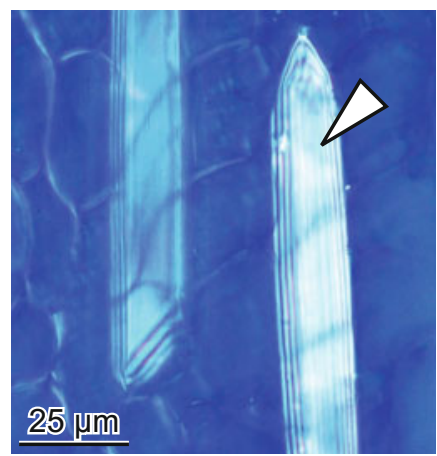

5.93 Elongated and layered crystal in the rhizome of Iris sibirica, polarized light. liana-like dwarf shrub Rubia tibetica, polarized light.

\section{Crystal arrangement in bark}

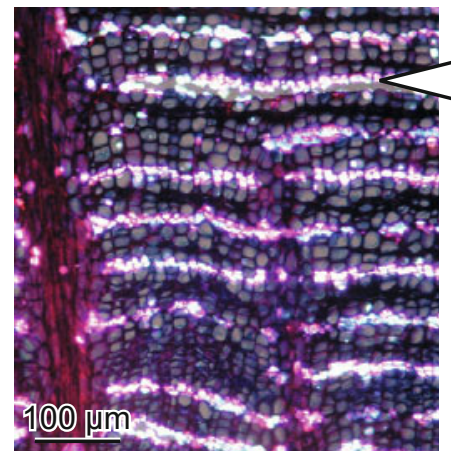

5.96 Tangentially arranged crystals in the phloem of the alpine shrub Ribes alpinum, polarized light.

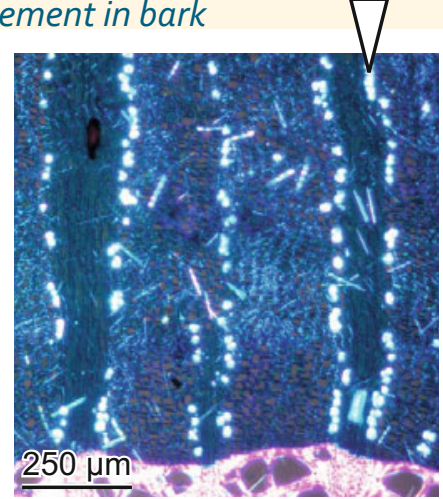

5.97 Radially arranged crystals along large rays in the phloem of the climber Parthenocissus inserta, polarized light.

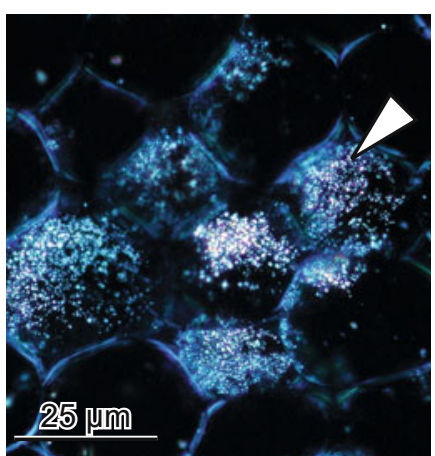

5.90 Crystal sand in cortex cells of the tropical Piper nigrum, polarized light.

\section{Crystals in chambers}

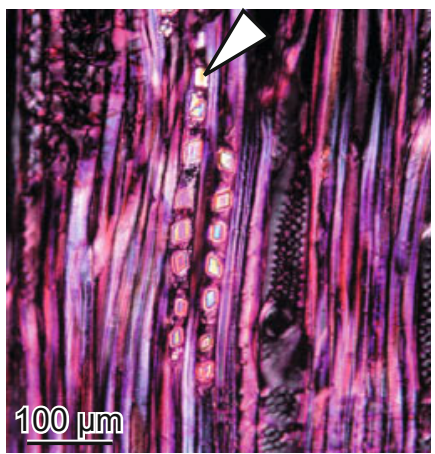

5.94 Prismatic crystals in a large idioblast (radial section) of the small shrub Neochamaelea pulverulenta, polarized light.

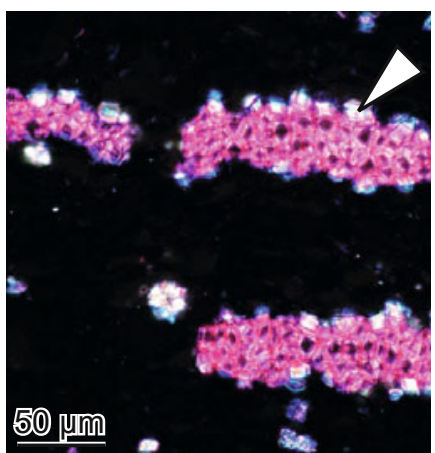

5.98 Prismatic crystals, arranged around fiber groups in the phloem of Salix purpurea, polarized light. 


\subsubsection{Stained substances within the stem - Defense}

Stained substances occur in the phloem, xylem and fruits of all vascular plants. Most obvious are discolorations in stems with heartwood, injuries or subfossil wood.

The term indicates the chemical and anatomical heterogeneity of the amorphic substances. Different terms are used, e.g. organic compounds, organic extractives, tannins (polyphenols), gums, resins and oils. Characteristic for all of them are the colors, which range without staining from yellow to red and dark brown, and with Astrablue/Safranin staining from blue to red and black.

A selective variety of different stained substances are presented, which occur in the xylem in vessels, axial and radial parenchyma cells, fibers and cells in the phloem. The producing cell structures are discussed in Chapter 4.12.

\section{Macroscopic aspect of dark-stained substances}

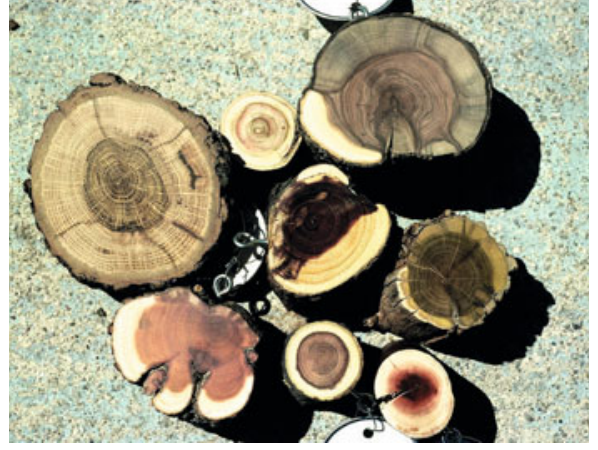

5.99 Dark-stained heartwood in various Australian wood species.

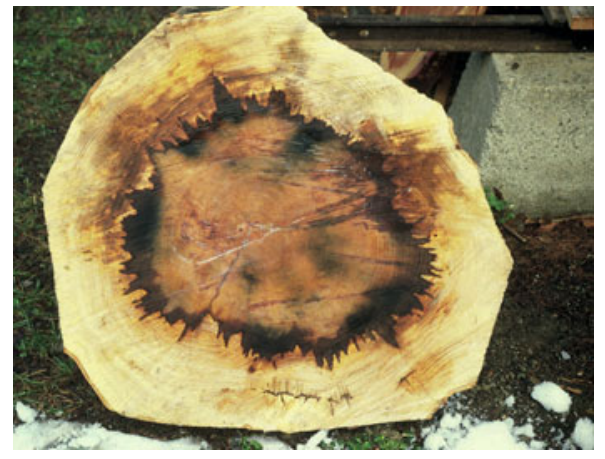

5.100 Dark-stained zones in biological defense zones (compartmentalization) of Fagus sylvatica.

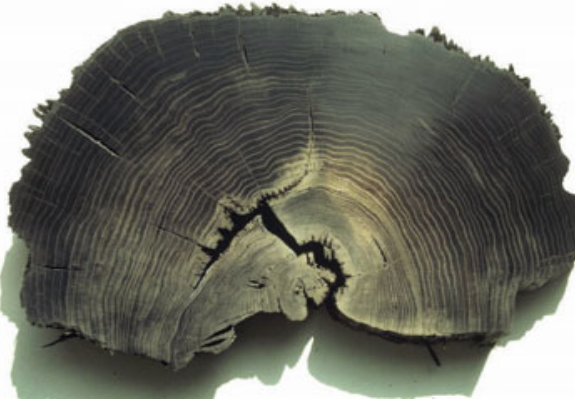

5.101 Dark-stained heartwood of a subfossil, waterlogged Quercus sp.

Stained substances in vessels

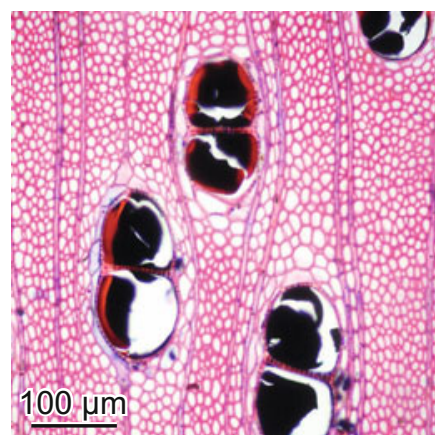

5.102 Black-stained substances in vessels of Acacia longifolia (Astrablue/Safranin-stained).

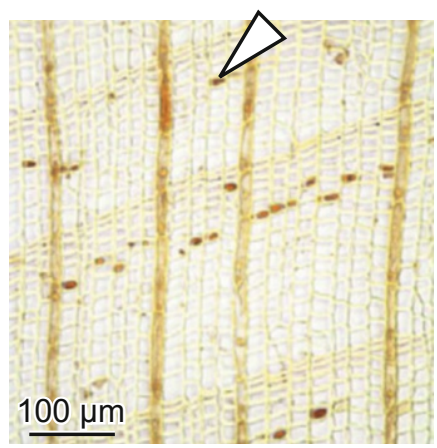

5.106 Brownish-stained substances in parenchyma cells in the heartwood of Juniperus communis (unstained).

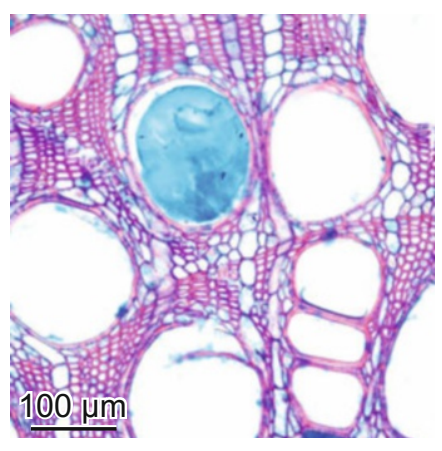

5.103 Dark-blue-stained substances in vessels and parenchyma cells in the heartwood of Juglans regia (Astrablue/Safranin-stained).

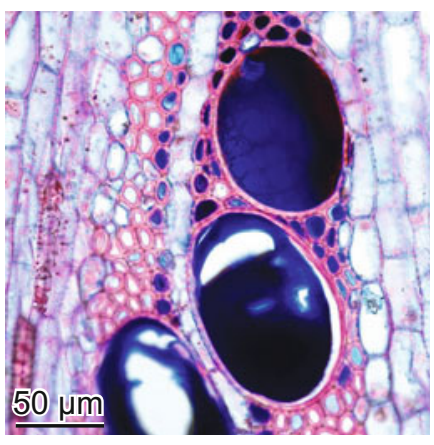

5.104 Dark-blue-stained substances in vessels of a Paliurus spina-christi (Astrablue/Safranin-stained)

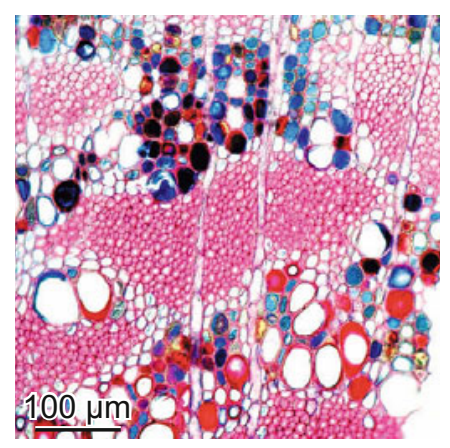

5.105 Black-, red-, blue- and yellowstained substances in vessels and vascular tracheids in Spartocytisus supranubius (Astrablue/Safranin-stained).
Stained substances in parenchyma cells

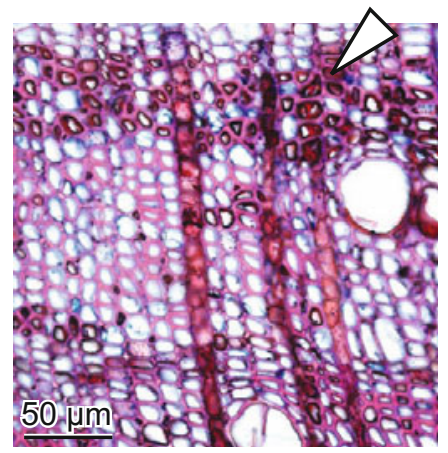

5.107 Dark-red-stained substances in axial and radial parenchyma cells in a chestnut-blight-affected Castanea sativa (Astrablue/Safranin-stained).

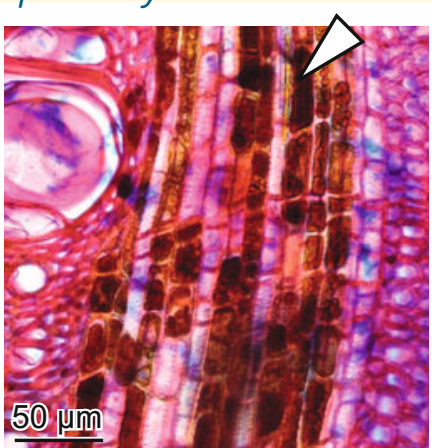

5.108 Brown-stained substances in a large ray of a dead part of the vine Vitis vinifera (Astrablue/Safraninstained).

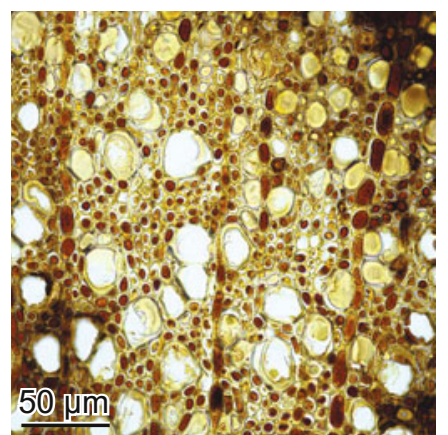

5.109 Brown-stained substances in parenchyma cells and fibers in the heartwood of the dwarf shrub Arctostaphylos uva-ursi (unstained). 
Stained substances in fibers and vessels

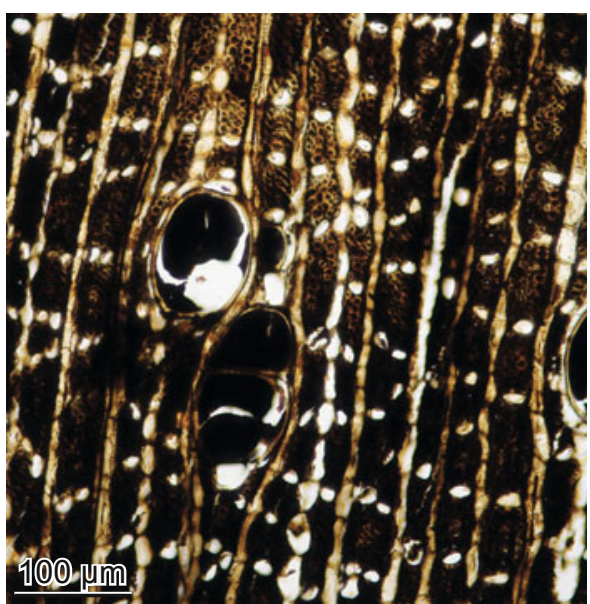

5.110 Brown-stained substances in vessels and fibers in the heartwood of ebony Diospyros sp. dark-stained substances.

Stained substances in subfossil wood

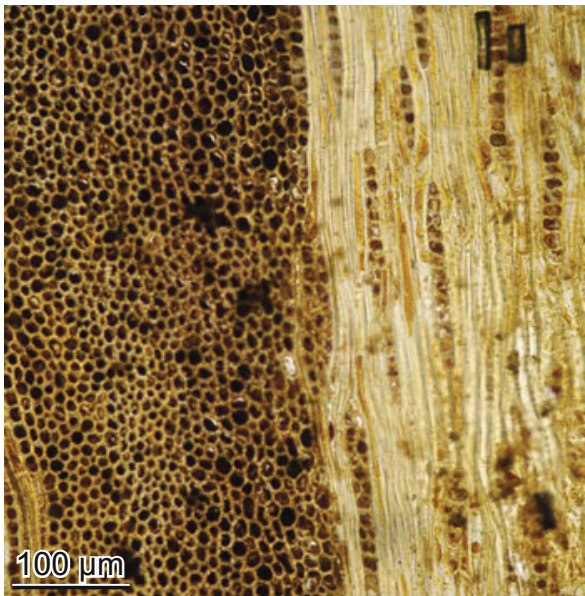

5.113 Brown-stained substances in ray cells of the black heartwood of a subfossil, waterlogged Quercus sp. (unstained). Fibers are slightly impregnated

Stained substances in cells of the phloem
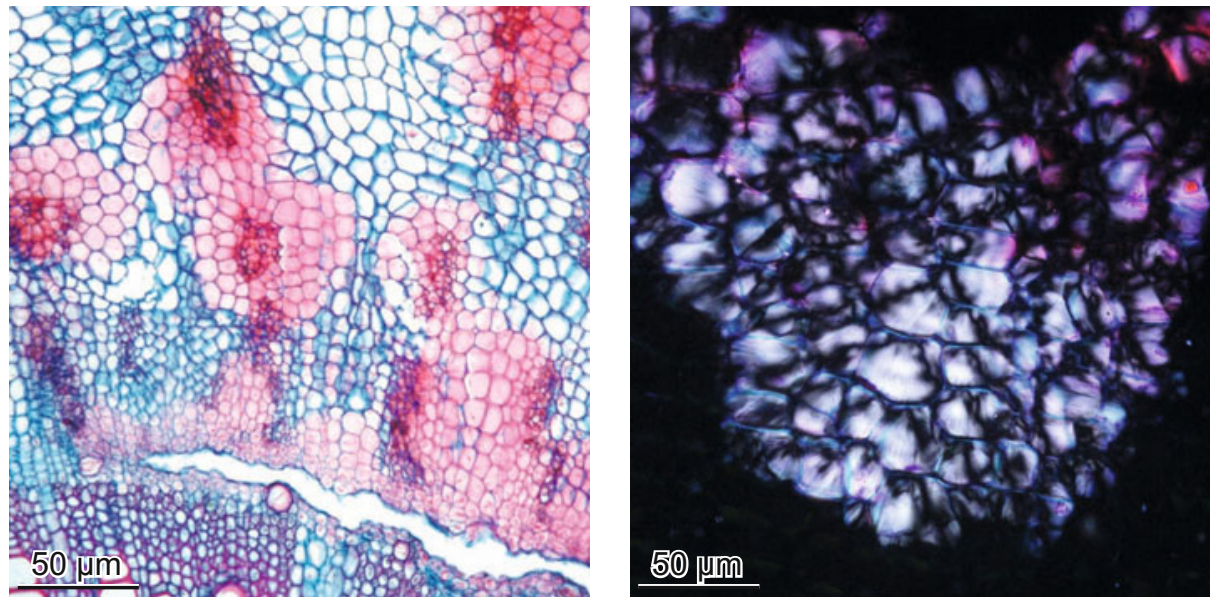

5.116 Red-stained substances around groups Safranin-stained).

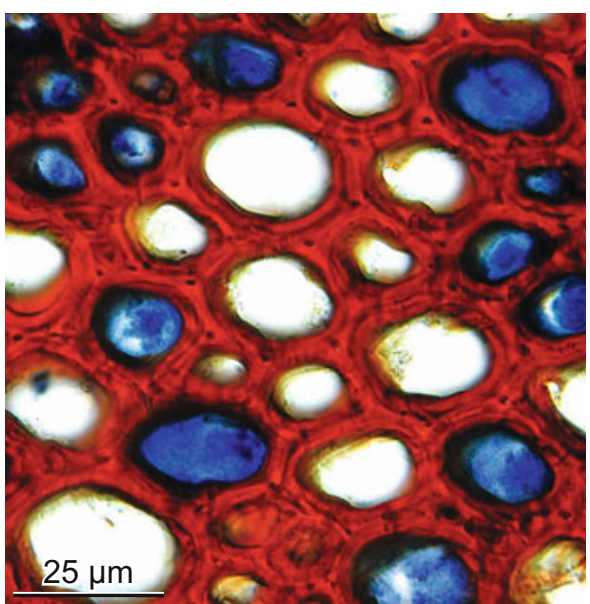

5.111 Red-stained substances in parenchyma umina of a rhizome of the fern Osmunda regalis (Astrablue/Safranin-stained).

Stained substances in cells of the phloem
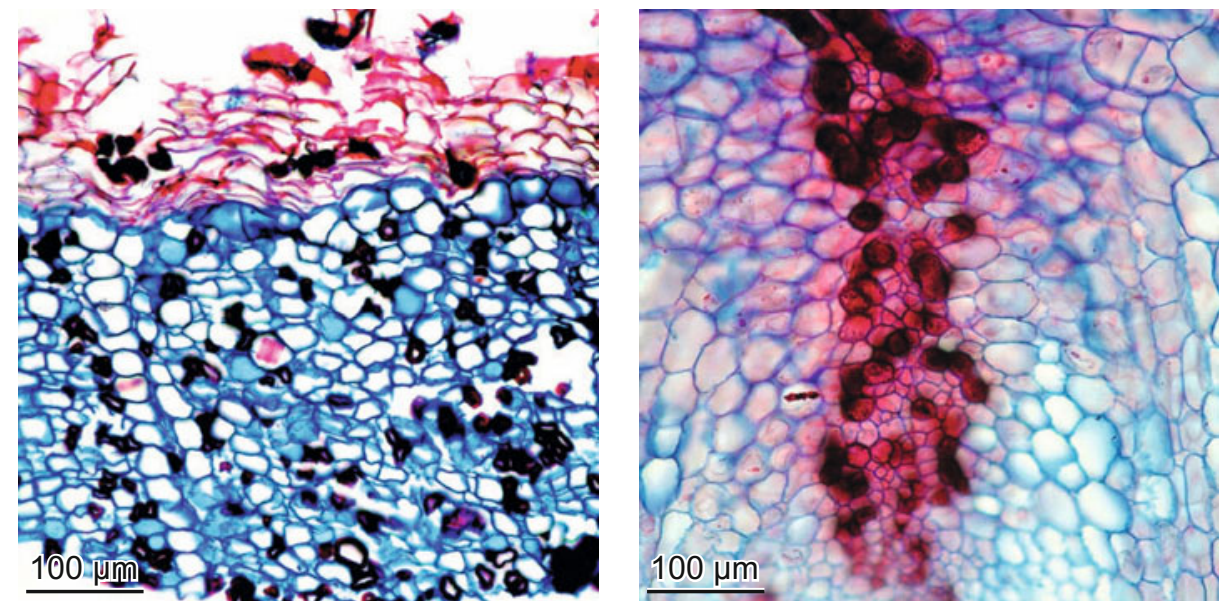

5.114 Black-stained substances in idioblasts in

(Astrablue/Safranin-stained)
Stained substances in decaying wood

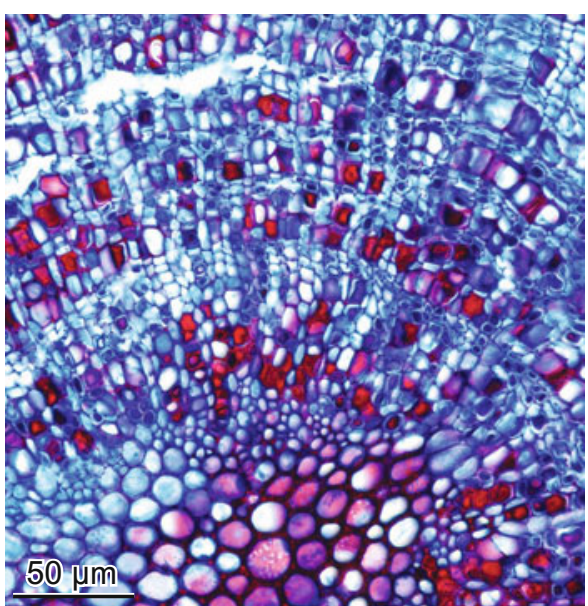

5.112 Red-stained substances in vessels of a delignified, decaying stem of the dwarf shrub Arctostaphylos alpina (Astrablue/Safranin-stained).
5.115 Dark-red-stained substances in parenchyma cells of the phloem of the herb Scorzonera graminifolia (Astrablue/Safranin-stained).

Stained substances in / around ducts

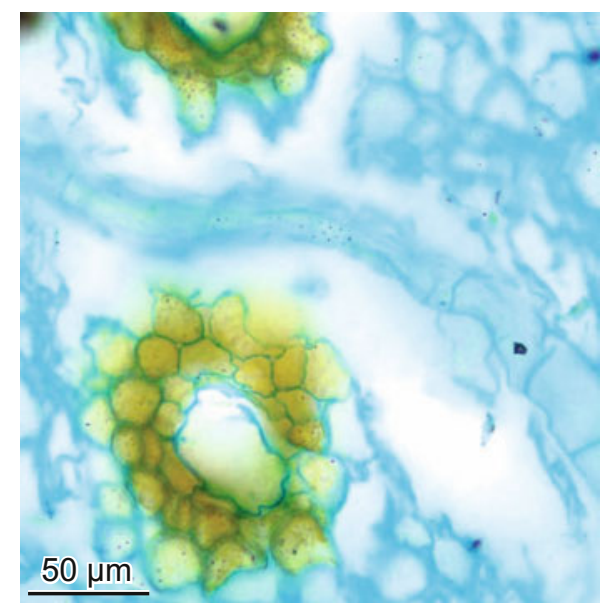

5.118 Yellow-stained substances, probably oil, around ducts in the phloem of the herb Herac leum pinnatum (Astrablue/Safranin-stained). 
Open Access This chapter is licensed under the terms of the Creative Commons Attribution 4.0 International License (http://creativecommons.org/licenses/by/4.0/), which permits use, sharing, adaptation, distribution and reproduction in any medium or format, as long as you give appropriate credit to the original author(s) and the source, provide a link to the Creative Commons license and indicate if changes were made.

The images or other third party material in this chapter are included in the chapter's Creative Commons license, unless indicated otherwise in a credit line to the material. If material is not included in the chapter's Creative Commons license and your intended use is not permitted by statutory regulation or exceeds the permitted use, you will need to obtain permission directly from the copyright holder. 